\title{
Towards Targeted Alpha Therapy with Actinium-225: Chelators for Mild Condition Radiolabeling and Targeting PSMA-A Proof of Concept Study
}

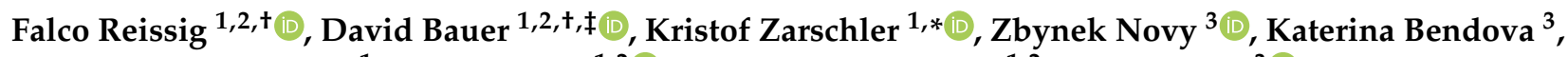 \\ Marie-Charlotte Ludik ${ }^{1}$, Klaus Kopka ${ }^{1,2}{ }^{\oplus}$, Hans-Jürgen Pietzsch ${ }^{1,2}$, Milos Petrik ${ }^{3}(\mathbb{C}$ \\ and Constantin Mamat $1,2, *$ (D)
}

check for updates

Citation: Reissig, F.; Bauer, D.; Zarschler, K.; Novy, Z.; Bendova, K.; Ludik, M.-C.; Kopka, K.; Pietzsch, H.-J.; Petrik, M.; Mamat, C. Towards Targeted Alpha Therapy with Actinium-225: Chelators for Mild Condition Radiolabeling and Targeting PSMA-A Proof of Concept Study. Cancers 2021, 13, 1974. https://doi.org/10.3390/ cancers13081974

Academic Editors: Stefano Fanti and Kambiz Rahbar

Received: 4 March 2021

Accepted: 15 April 2021

Published: 20 April 2021

Publisher's Note: MDPI stays neutral with regard to jurisdictional claims in published maps and institutional affiliations.

Copyright: (c) 2021 by the authors. Licensee MDPI, Basel, Switzerland. This article is an open access article distributed under the terms and conditions of the Creative Commons Attribution (CC BY) license (https:// creativecommons.org/licenses/by/ $4.0 /)$.
1 Helmholtz-Zentrum Dresden-Rossendorf, Institute of Radiopharmaceutical Cancer Research, Bautzner Landstraße 400, D-01328 Dresden, Germany; f.reissig@hzdr.de (F.R.); BauerD1@mskcc.org (D.B.); m.ludik@hzdr.de (M.-C.L.); k.kopka@hzdr.de (K.K.); h.j.pietzsch@hzdr.de (H.-J.P.)

2 Faculty of Chemistry and Food Chemistry, Technische Universität Dresden, D-01062 Dresden, Germany

3 Institute of Molecular and Translational Medicine, Faculty of Medicine and Dentistry, Palacky University Olomouc, Hnevotinska 1333/5, 77900 Olomouc, Czech Republic; zbynek.novy@upol.cz (Z.N.); katerina.bendova01@upol.cz (K.B.); milos.petrik@upol.cz (M.P.)

* Correspondence: k.zarschler@hzdr.de (K.Z.); c.mamat@hzdr.de (C.M.)

$\dagger \quad$ These authors contributed equally.

$\ddagger$ Current address: Molecular Pharmacology Program, Memorial Sloan Kettering Cancer Center, 1275 York Avenue, New York, NY 10065, USA.

Simple Summary: In nuclear medicine, therapeutic methods are used increasingly, in which tumors are destroyed by ionizing radiation that cannot or can only be treated insufficiently by other methods like surgery or chemotherapy. Targeted alpha therapy (TAT) is a promising method with increasing importance that facilitates new treatment options for advanced and late-stage cancer diseases. The effectiveness of alpha-emitting radionuclides is characterized by a higher linear energy transfer and a higher biological efficacy, compared to therapeutic approaches with beta emitters. ${ }^{225} \mathrm{Ac}$ is an alpha emitter with favorable nuclear properties for radiopharmaceutical applications. The aim of our research was to find a universal chelator that enables the attachment of sensitive bio(macro)molecules and allows ${ }^{225}$ Ac-radiolabeling under mild conditions. An aza-macrocycle-derived mcp chelator with functional groups for universal connection of biomolecules using convenient click chemistry was developed for the ${ }^{225}$ Ac-labeling. The resulting ${ }^{225}$ Ac-radioconjugates were analyzed in vitro and in vivo, showing a high receptor affinity on tumor cells and a high tumor accumulation in tumor-bearing mice.

Abstract: Currently, targeted alpha therapy is one of the most investigated topics in radiopharmaceutical cancer management. Especially, the alpha emitter ${ }^{225}$ Ac has excellent nuclear properties and is gaining increasing popularity for the treatment of various tumor entities. We herein report on the synthesis of two universal ${ }^{225} \mathrm{Ac}$-chelators for mild condition radiolabeling and binding to conjugate molecules of pharmacological interest via the copper-mediated click chemistry. A convenient radiolabeling procedure was investigated as well as the complex stability proved for both chelators and two PSMA (prostate-specific membrane antigen)-targeting model radioconjugates. Studies regarding affinity and cell survival were performed on LNCaP cells followed by biodistribution studies, which were performed using LNCaP tumor-bearing mice. High efficiency radiolabeling for all conjugates was demonstrated. Cell binding studies revealed a fourfold lower cell affinity for the PSMA radioconjugate with one targeting motif compared to the radioconjugate owing two targeting motifs. Additionally, these differences were verified by in vitro cell survival evaluation and biodistribution studies, both showing a higher cell killing efficiency for the same dose, a higher tumor uptake $(15 \% \mathrm{ID} / \mathrm{g})$ and a rapid whole body clearance after $24 \mathrm{~h}$. The synthesized chelators will overcome obstacles of lacking stability and worse labeling needs regarding ${ }^{225}$ Ac complexation using the DOTA (1,4,7,10-tetraazacyclododecane-1,4,7,10-tetrayl)tetraacetic acid) chelator. Moreover, 
the universal functionalization expands the coverage of these chelators in combination with any sensitive bio(macro)molecule, thus improving treatment of any addressable tumor target.

Keywords: actinium-225; PSMA; theranostics; targeted alpha therapy; click chemistry

\section{Introduction}

Targeted alpha therapy (TAT) provides new treatment options for advanced and late-stage cancer diseases but also offers new possibilities for radiopharmaceutical cancer research. Compared to other therapies (e.g., external radiotherapy and radioligand therapy (RLT) based on beta emitters), TAT is putatively more efficient in eliciting cell death due to the exceedingly high ionizing density. The short range of alpha particles minimizes the unwanted irradiation for surrounding healthy tissue and reduces possible side effects [1] Unfortunately, only a few alpha-emitting radionuclides are currently available, owing appropriate qualities for medical applications.

Besides the alpha-emitting radionuclide astatine-211, which is covalently bound to the targeting moiety [2-5], today's focus lies on radiometals, particularly on bismuth and radium radionuclides, as well as on thorium-227 and actinium-225 [6,7]. Each radiometal has its advantages and obstacles. Bismuth-212 $\left(\mathrm{t}_{1 / 2}=61 \mathrm{~min}\right)$ or the lead-212/bismuth-212 in vivo generator system and bismuth-213 $\left(\mathrm{t}_{1 / 2}=46 \mathrm{~min}\right)$ showed promising results in clinical and preclinical studies [8,9]. Still, there is a lack of applications, most likely induced by the high amount of administered activities resulting in adverse reactions and a loss of flexibility due to the short half-lives. Radium-223 $\left(t_{1 / 2}=11 \mathrm{~d}\right)$ and radium-224 $\left(t_{1 / 2}=3.6 \mathrm{~d}\right)$ possess suitable physical properties by emitting multiple alpha particles in their decay chains with total decay energies of about $30 \mathrm{MeV}$ resulting in a high linear energy transfer. Xofigo ${ }^{\circledR}$ is the only clinically relevant application with EMA- and FDA-approval for radium-223 to date and is used in the form of $\left[{ }^{223} \mathrm{Ra}^{2} \mathrm{RaCl}_{2}\right.$ to treat metastatic prostate cancer [10]. The major limitation of radium is the lack of an organic or inorganic framework to bind this radionuclide stably [11]. Despite several approaches to coordinate $\mathrm{Ra}^{2+}$, (e.g., using macrocyclic ligands [12-15], inorganic nanomatrices such as nanoparticles based on $\mathrm{BaSO}_{4}[16,17]$, barium ferrite [18], $\mathrm{TiO}_{2}$ and hydroxyapatite $[19,20]$ or polyoxometalates [21]), an ideal carrier was not found, yet.

During the last decade, the radiometals actinium-225 $\left(\mathrm{t}_{1 / 2}=10 \mathrm{~d}\right)$ and thorium-227 $\left(t_{1 / 2}=19 d\right)$ gained relevance as promising alpha emitters suitable for future targeting radiotherapeutics. Thorium-227-labeled antibody-Me-3,2-HOPO-conjugates are currently investigated in four clinical phase I trials [22,23]. Eleven clinical trials are displayed for actinium-225-DOTA-based conjugates. A trial of $\left[{ }^{225}\right.$ Ac]Ac-PSMA-617 in men with PSMApositive prostate cancer is projected to start this year [24]. Actinium-225 can easily be complexed with the DOTA chelator, but requires high temperatures $\left(80-95^{\circ} \mathrm{C}\right)$ or microwave assistance [23]. However, first studies showed that the chelator macropa (mcp) might be even more suitable [25]. This diaza-18-crown-6-based chelator, substituted with two picolinate moieties, is known to form exceedingly stable actinium complexes, requiring mild conditions and ambient temperature for labeling [26]. Remarkably, complexation at ambient temperature allows direct radiolabeling of even heat-sensitive bio(macro)molecules such as antibodies and antibody fragments [27].

Our recent work focuses on new macropa-based ligands for the development of actinium-225-conjugates, combining both the extremely high complex stability and a clickable functionalization site for attaching biological targeting molecules. We aimed to synthesize a chelator, which can be functionalized for conjugations using click chemistry by the [3+2] Huisgen cycloaddition approach (CuAAC). For this purpose, we designed two propargyl-functionalized mcp-chelators based on the diaza-18-crown-6-skeleton. In a preclinical proof-of-concept-study, this chelator was conjugated to an azide-functionalized carboxylic acid as well as an azide-functionalized PSMA-binding motif. We compared the 
radiolabeling efficiency of our new chelators and their PSMA conjugates, performed cellbinding affinity and colony survival assays on PSMA-positive human prostate adenocarcinoma (LNCaP) cells. Finally, both new tracers were characterized regarding biodistribution in healthy and LNCaP tumor-bearing mice.

\section{Results}

\subsection{Chelator Development}

Our new targeting conjugates for an improved radiolabeling with actinium-225 are based on a macropa-derived chelator and the well-characterized targeting biomolecule PSMA-617. We designed two chelators functionalized either with one or two alkyne moieties for an easy and quick conjugation with biomolecules of interest using the coppercatalyzed azide-alkyne-cycloaddition reaction [28]. For comparison, we synthesized the chelator macropa according to previously published procedures [29]. The synthesis of the novel mono- and di-alkyne-modified chelators mcp-M-click and mcp-D-click is presented in Scheme 1.

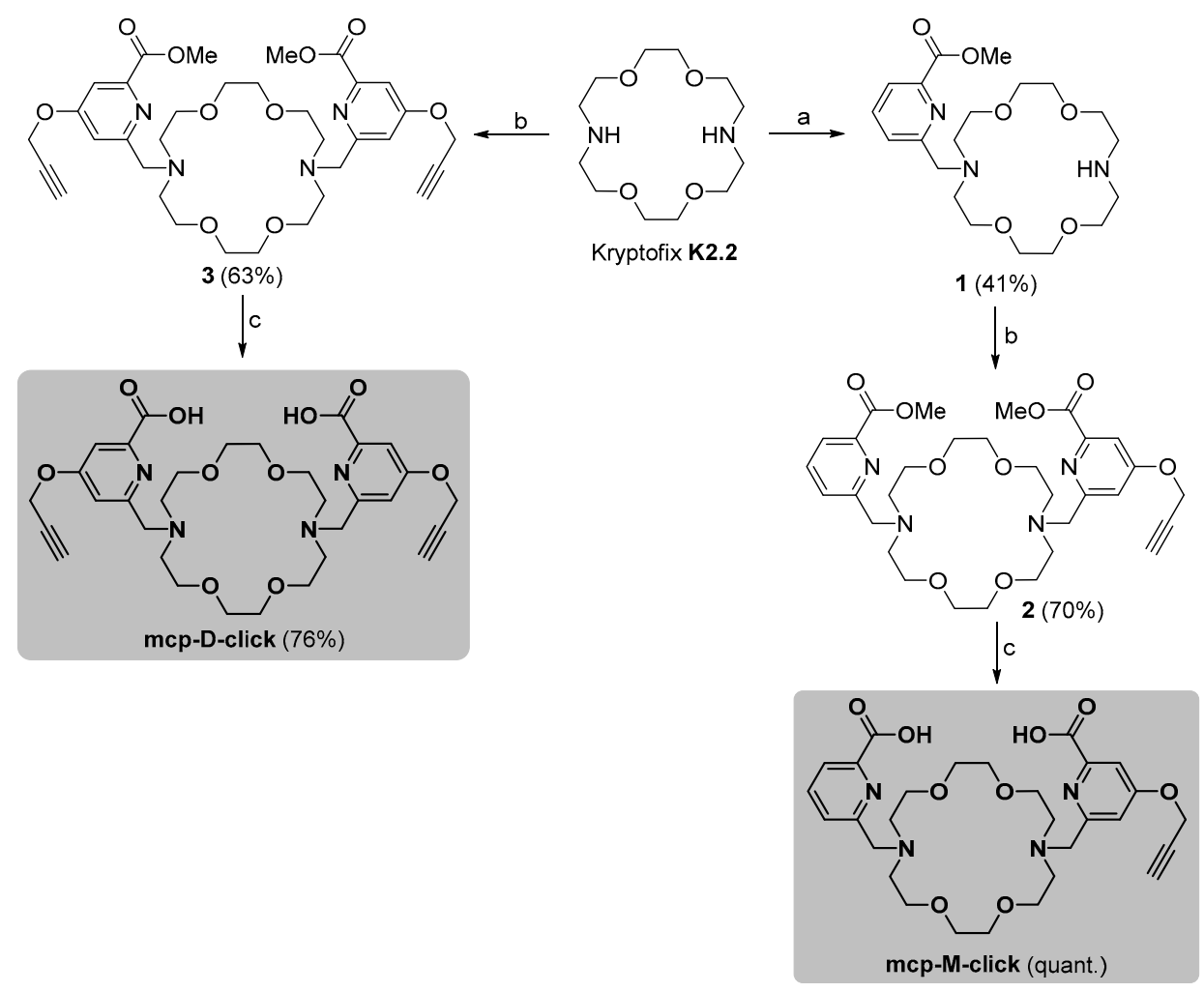

Scheme 1. Synthesis for the macropa-derived, alkyne-functionalized chelators mcp-M-click and mcp-D-click. Reaction conditions: (a) Methyl 6-(chloromethyl)picolinate, $N, N$-diisopropylethylamine, acetonitrile, reflux, overnight; (b) methyl 6-(chloromethyl)-4-(prop-2-yn-1-yloxy)picolinate (SI-III, see Scheme S1), N,N-diisopropylethylamine, acetonitrile, reflux, overnight; (c) lithium hydroxide, water/methanol, $50{ }^{\circ} \mathrm{C}, 4 \mathrm{~h}$.

Both novel universal clickable chelators are based on 4,13-diaza-18-crown-6 (Kryptofix K2.2). For the monofunctionalization, K2.2 was reacted with methyl 6-(chloromethyl)picolinate to give the diazacrown derivative 1 . To introduce the clickable alkyne-function, compound 1 was reacted with methyl 6-(chloromethyl)-4-(prop-2-yn-1-yloxy)picolinate (SI-III). The preparation of SI-III is expressed in the Supporting Information, Scheme S1 and Figures S1-S3). The resulting dimethyl ester $\mathbf{2}$ was finally saponified with lithium hydroxide to provide the monoalkyne chelator mcp-M-click. To obtain the bis-alkyne derivative mcp-D-click, K2.2 was reacted with SI-III in excess to yield the respective symmetric diester $\mathbf{3}$ with two alkyne functions, which was finally saponified with lithium hydroxide. 
Both PSMA conjugates mcp-M-PSMA and mcp-D-PSMA were finally synthesized under click chemistry conditions (CuAAC) by incubating the chelators mcp-M-click and

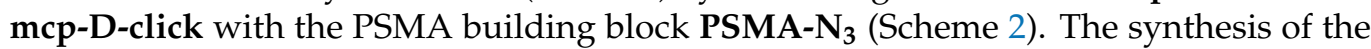
click building block PSMA- $\mathbf{N}_{3}$, which is based on the PSMA-617 binding motif, is described in the Supporting Information (Scheme S3, Figures S5 and S6). In addition, the model chelator $\mathbf{m c p}-\mathbf{M}-\mathbf{C O O H}$ was prepared under the conditions mentioned before (see SI, Scheme S2 and Figure S4).
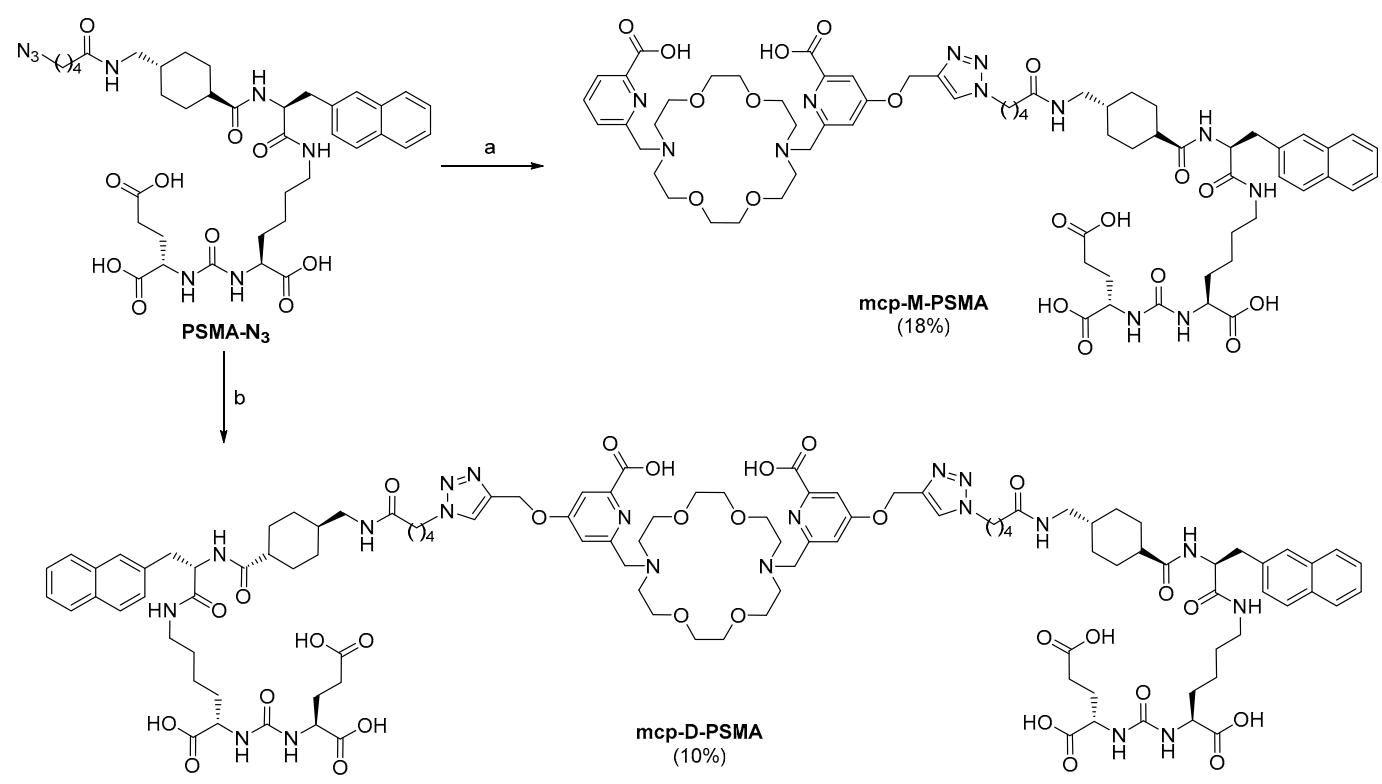

Scheme 2. Synthesis of the monomeric and dimeric PSMA-targeting structure mcp-M-PSMA and mcp-DPSMA. Reaction conditions: (a) mcp-M-click, $\left[\left(\mathrm{CH}_{3} \mathrm{CN}\right)_{4} \mathrm{Cu}\right] \mathrm{PF}_{6}$, tris[(1-benzyl-1H-1,2,3-triazol-4-yl)methyl]amine, $\mathrm{N}, \mathrm{N}$-dimethylformamide, room temperature, overnight; (b) mcp-D-click, $\left[\left(\mathrm{CH}_{3} \mathrm{CN}\right)_{4} \mathrm{Cu}\right] \mathrm{PF}_{6}$, tris[(1-benzyl-1H-1,2,3-triazol4-yl)methyl]amine, $\mathrm{N}, \mathrm{N}$-dimethylformamide, room temperature, overnight.

\subsection{Radiolabeling and Complex Stability}

To compare the efficiency of the synthesized chelators and their conjugates, $100 \mathrm{kBq}$ of actinium-225 were incubated with each ligand at different concentrations $\left(10^{-5} \mathrm{M} ; 10^{-6} \mathrm{M}\right.$; $10^{-7} \mathrm{M}$ ). The radiochemical yield was determined after one hour of reaction time using normal phase and reversed-phase TLC. Whereas one TLC-system was designed to move free actinium-225 with the solvent front, the other system was developed only to move the actinium-225 labeled complexes. Concentration-dependent radiochemical yields for all ligands and 7-day-longterm yields, which were calculated using both TLC systems, are presented in Table 1.

All investigated ligands show excellent complex formation abilities with $\left[{ }^{225} \mathrm{Ac}\right] \mathrm{Ac}^{3+}$, even at the low ligand concentration of $10^{-7} \mathrm{M}$. No activity-release was detected over seven days. Furthermore, the improved labeling yields obtained at the lowest concentrations after seven days showing that complexation might not be finished after one hour. Comparing mcp-M-click and mcp-D-click with the non-functionalized reference ligand macropa, the slight difference in the affinity might result from the steric hindrance caused by the propargyl moiety. A further enhancement even in yields at low concentrations and longtime stabilities was found using the model conjugate $\left[{ }^{225} \mathrm{Ac}\right] \mathrm{Ac}-\mathrm{mcp}-\mathrm{M}-\mathrm{COOH}$ containing an additional triazole moiety, presumably due to the additional nitrogen donor atom. $\left[{ }^{225} \mathrm{Ac}\right] \mathrm{Ac}-\mathrm{mcp}-\mathrm{M}-\mathrm{COOH}$ thereby predicts excellent labeling properties for the PSMA conjugates as well. Higher yields were obtained as well using the PSMA-functionalized conjugates mcp-M-PSMA and mcp-D-PSMA. 
Table 1. ${ }^{225}$ Ac-labeling of selected ligands in a serial dilution. Radiochemical yields (RCY) determined after $1 \mathrm{~h}$ of reaction time at room temperature and after seven days (NP: normal phase; RP: reversed-phase).

\begin{tabular}{|c|c|c|c|c|c|c|c|c|c|c|c|c|c|c|c|c|c|c|}
\hline \multirow{2}{*}{$\begin{array}{c}\mathbf{R C Y}(\%) \\
\mathrm{C}[\mathrm{M}]\end{array}$} & \multicolumn{3}{|c|}{$\begin{array}{l}{\left[{ }^{225} \mathrm{Ac}\right] \mathrm{Ac}-} \\
\text { macropa }\end{array}$} & \multicolumn{3}{|c|}{$\begin{array}{c}{\left[{ }^{225} \text { Ac]Ac-mcp- }\right.} \\
\text { M-click }\end{array}$} & \multicolumn{3}{|c|}{$\begin{array}{c}{ }^{225} \text { Ac]Ac-mcp- } \\
\text { D-click }\end{array}$} & \multicolumn{3}{|c|}{$\begin{array}{c}{\left[{ }^{225} \text { Ac]Ac-mcp- }\right.} \\
\text { M-COOH }\end{array}$} & \multicolumn{3}{|c|}{$\begin{array}{c}{\left[{ }^{225} \text { Ac]Ac-mcp- }\right.} \\
\text { M-PSMA }\end{array}$} & \multicolumn{3}{|c|}{$\begin{array}{c}\left.{ }^{225} \mathrm{Ac}\right] \mathrm{Ac}-\mathrm{mcp}- \\
\text { D-PSMA }\end{array}$} \\
\hline & $10^{-5}$ & $10^{-6}$ & $10^{-7}$ & $10^{-5}$ & $10^{-6}$ & $10^{-7}$ & $10^{-5}$ & $10^{-6}$ & $10^{-7}$ & $10^{-5}$ & $10^{-6}$ & $10^{-7}$ & $10^{-5}$ & $10^{-6}$ & $10^{-7}$ & $10^{-5}$ & $10^{-6}$ & $10^{-7}$ \\
\hline NP $(1 \mathrm{~h})$ & 99 & 99 & 56 & 99 & 99 & 20 & 99 & 99 & 52 & 99 & 99 & 98 & 99 & 99 & 89 & 99 & 99 & 93 \\
\hline $\mathrm{NP}(7 \mathrm{~d})$ & 99 & 99 & 99 & 99 & 99 & 58 & 99 & 99 & 50 & 99 & 99 & 99 & 99 & 99 & 99 & 99 & 99 & 95 \\
\hline $\mathrm{RP}(1 \mathrm{~h})$ & 99 & 90 & 37 & 96 & 97 & 23 & 99 & 99 & 41 & 99 & 98 & 98 & / & / & / & / & / & / \\
\hline $\mathrm{RP}(7 \mathrm{~d})$ & 99 & 99 & 99 & 99 & 99 & 55 & 99 & 94 & 40 & 99 & 99 & 96 & / & / & / & / & / & / \\
\hline
\end{tabular}

Unfortunately, a suitable reversed-phase iTLC system for the ligands mcp-M-PSMA and mcp-D-PSMA was not found so far to determine the radiochemical yields. The resolution of our standard system was not efficient, most likely due to the bigger size of these molecules compared to the basic chelators, different protonation steps and possible conformational structures. Additionally, $\log \mathrm{D}_{7.4}$ values were determined to be $-2.8 \pm 0.1$ for the complex [ $\left.{ }^{225} \mathrm{Ac}\right] \mathrm{Ac}-\mathrm{mcp}-\mathrm{M}-\mathrm{PSMA}$ and $-2.5 \pm 0.1$ for the complex $\left[{ }^{225} \mathrm{Ac}\right] \mathrm{Ac}-\mathrm{mcp}-$ D-PSMA, respectively. Additionally, the stability of the ${ }^{225}$ Ac-labeled conjugates in acetate buffer was investigated by HPLC analyses over a period of ten days. Representative chromatograms of $\left[{ }^{225} \mathrm{Ac}\right]$ Ac-mcp-M-PSMA and $\left[{ }^{225} \mathrm{Ac}\right]$ Ac-mcp-D-PSMA with and without the addition of the antioxidant excipients ascorbic acid (Asc) or 2,5-dihydroxybenzoic acid (DHB), respectively, are shown in Figure 1.
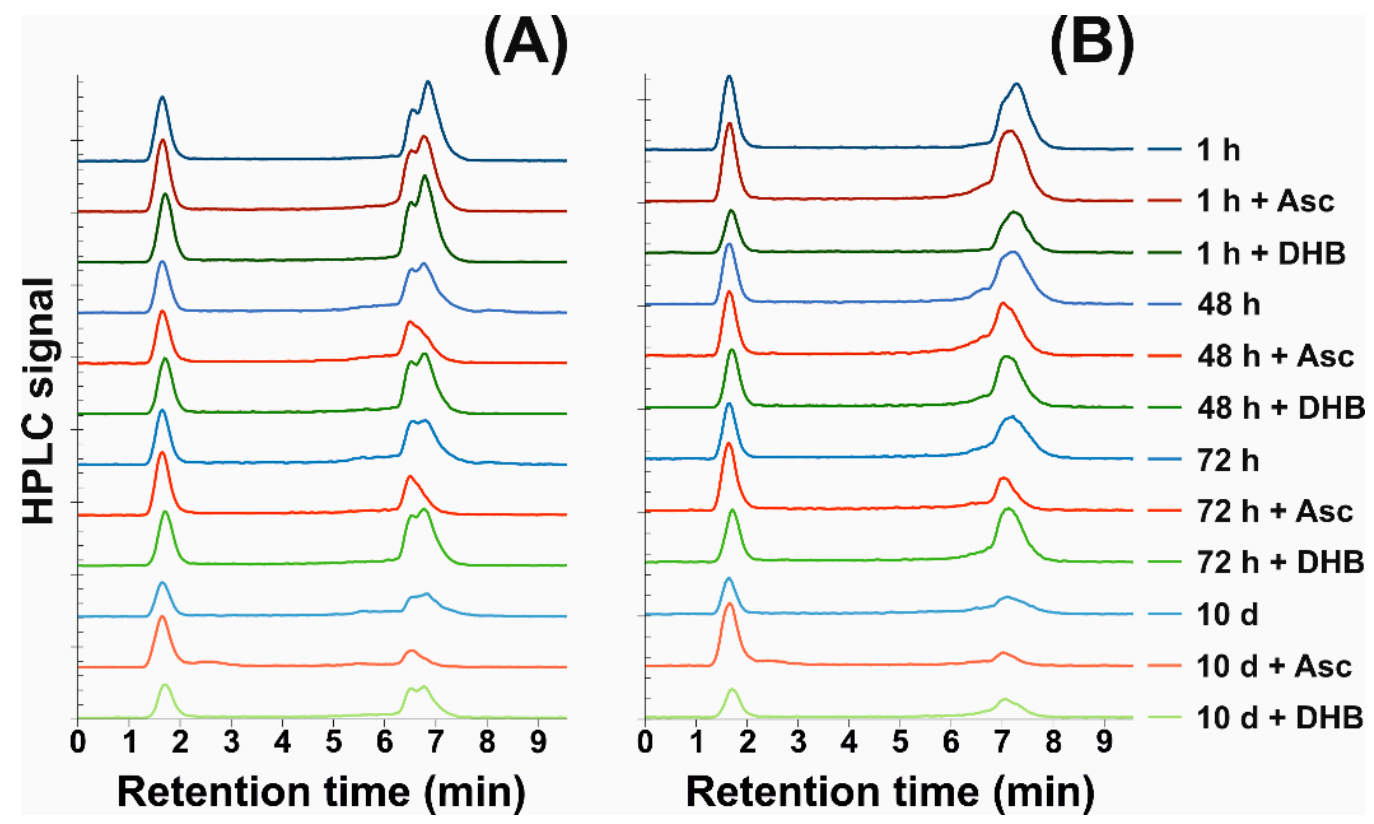

Figure 1. Radio-HPLC chromatograms for radiolabeled mcp-M-PSMA (A) and mcp-D-PSMA (B) in acetate buffer, pH 6 at room temperature in the absence and presence of stabilizers as a function of time. Samples were incubated with or without $0.1 \mathrm{M}$ ascorbic acid (Asc) or $0.1 \mathrm{M}$ 2,5-dihydroxy benzoic acid (DHB), respectively.

The radio-HPLC-chromatograms in Figure 1 show two to three signals originating from radionuclides of the actinium-225 decay chain. Consequently, analyses of the respective HPLC fractions were performed using a high resolution gamma detector. The peak with a retention time of $\sim 1.8 \mathrm{~min}$ was identified to be uncomplexed francium-221. The other two signals were identified as a mixture of $\left[{ }^{213} \mathrm{Bi}\right] \mathrm{Bi}$ - and $\left[{ }^{225} \mathrm{Ac}\right] \mathrm{Ac}$-labeled PSMA conjugates.

Regarding the intensively discussed side-effects that are often caused by daughter nuclides, this could be an additional advantage when the chelators form stable complexes with 
both metal ions actinium-225 and bismuth-213. Nevertheless, recoiling daughter nuclides like bismuth-213 remains an aspect to be considered [30,31], since breaking of chemical bonds represents an inevitable result of alpha decay no matter which chelator is used.

Most importantly, radiolabeled mcp-M-PSMA as well as mcp-D-PSMA are stable in acetate buffer at room temperature for at least $48 \mathrm{~h}$ without antioxidants as demonstrated in Figure 1. However, the addition of $0.1 \mathrm{M}$ DHB increases the stability of both PSMA derivatives by preventing radiolytic degradation to a certain extent. The presence of $0.1 \mathrm{M}$ ascorbic acid did not stabilize the ${ }^{225}$ Ac-labeled conjugates and led to less complex stability and transchelation (verified by TLC). Although DHB appears to be more effective than ascorbic acid in retarding the dissociation by ionizing radiation, that might not apply for other ${ }^{225}$ Ac-based radiopharmaceuticals. Therefore, we conclude that the stability evaluation and stabilization needs to be assessed for each individual radioconjugate. In contrast to other previously published results on crown-based actinium-chelators [32], we do not conclude that actinium and alpha particle emitting radiopharmaceuticals in general, are only applicable in the first hours after production. To the best of our knowledge, future pharmaceuticals using our radioconjugate would not have to be produced in-house solely and possess adequate stability at an appropriate molar activity of $5 \mathrm{MBq} / \mathrm{nmol}$ (regarding the total ligand amount).

\subsection{Characterization of the PSMA-Binding Properties}

Saturation binding studies using PSMA-positive LNCaP cells (see SI, Figures S14 and S15 for PSMA expression analysis) in combination with radiolabeled mcp-M-PSMA or mcp-D-PSMA, respectively, were performed to evaluate the binding specificity and affinity of the PSMA targeting variants. Incubation of $\left[{ }^{225} \mathrm{Ac}\right] \mathrm{Ac}-\mathrm{mcp}-\mathbf{M}-\mathbf{P S M A}$ or $\left[{ }^{225} \mathrm{Ac}\right] \mathrm{Ac}-\mathrm{mcp}-$ D-PSMA (30 nM) with LNCaP cells revealed a specific binding to PSMA, which was blocked significantly by the addition of an excess of PSMA-617 (Figure 2).

$\square$ Total binding

Nonspecific binding

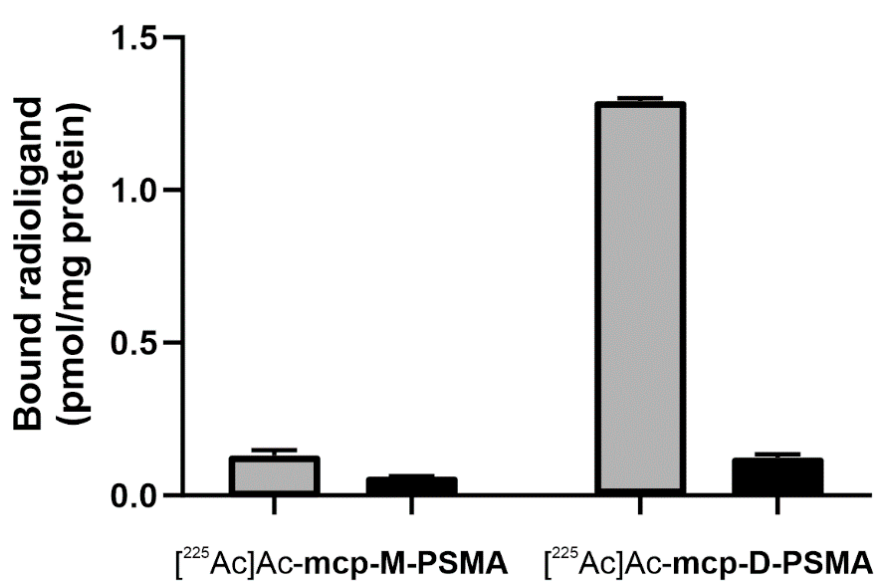

Figure 2. Binding specificity of $\left[{ }^{225} \mathrm{Ac}\right] \mathrm{Ac}-\mathrm{mcp}-\mathrm{M}-\mathrm{PSMA}$ and $\left[{ }^{225} \mathrm{Ac}\right] \mathrm{Ac}-\mathrm{mcp}-\mathrm{D}-\mathrm{PSMA}$ was determined by total binding (non-blocked) and nonspecific binding to PSMA-positive LNCaP cells, the latter by co-incubation with a 1000-fold molar excess of unlabeled PSMA-617 $(n=3)$.

Specific binding of the dimeric compound $\left[{ }^{225} \mathrm{Ac}\right] \mathrm{Ac}-\mathrm{mcp}-\mathrm{D}-\mathrm{PSMA}$ was approximately ninefold higher than that of the monomeric counterpart $\left[{ }^{225} \mathrm{Ac}\right] \mathrm{Ac}-\mathrm{mcp}-\mathrm{M}-\mathrm{PSMA}$ ( 1.17 vs. $0.07 \mathrm{pmol} / \mathrm{mg}$ protein). After incubation of LNCaP cells with a serial dilution of $\left[{ }^{225}\right.$ Ac]Ac-mcp-M-PSMA or [ ${ }^{225}$ Ac]Ac-mcp-D-PSMA, respectively, the equilibrium dissociation constants $\mathrm{K}_{\mathrm{d}}$ were calculated by the GraphPad Prism software using a "One site-total and nonspecific binding" analysis (Figure 3$)$. A $\mathrm{K}_{\mathrm{d}}$ of $(38.44 \pm 8.22) \mathrm{nM}$ and a 
$\mathrm{B}_{\max }$ of $(0.163 \pm 0.011) \mathrm{pmol} / \mathrm{mg}$ protein were determined for [ $\left.{ }^{225} \mathrm{Ac}\right] \mathrm{Ac}-\mathrm{mcp}-\mathbf{M}-\mathbf{P S M A}$, whereas a $K_{d}$ of $(9.92 \pm 0.62) \mathrm{nM}$ and a $B_{\max }$ of $(1.528 \pm 0.023) \mathrm{pmol} / \mathrm{mg}$ protein were calculated for $\left[{ }^{225} \mathrm{Ac}\right]$ Ac-mcp-M-PSMA. The obtained data indicate an improved binding affinity of the dimeric derivative compared to the monomer. These results are in line with findings published by Schäfer et al. [33] and Frei et al. [34] revealing the outperforming cell binding and uptake properties of dimeric PSMA samples. The presence of two independent PSMA-binding motifs within the dimeric $\left[{ }^{225} \mathrm{Ac}\right]$ Ac-mcp-D-PSMA allows the compound to bind first with one motif to the respective antigen. The remaining (unoccupied) binding motif is now in close spatial proximity to other target sites on the cell surface and can bind to a second PSMA receptor. This divalent binding behavior stabilizes the $\left[{ }^{225} \mathrm{Ac}\right] \mathrm{Ac}-\mathrm{mcp}-\mathrm{D}-$ PSMA interaction as transient unbinding of a single site does not necessarily result in the release of the captured compound unless the dissociation occurs at both sites [35]. Accordingly, the equilibrium dissociation constant of the monomeric $\left[{ }^{225} \mathrm{Ac}\right]$ Ac-mcp-M-PSMA is approximately three times higher than that of the dimeric compound, suggesting that monovalent binding is less stable than bivalent binding.
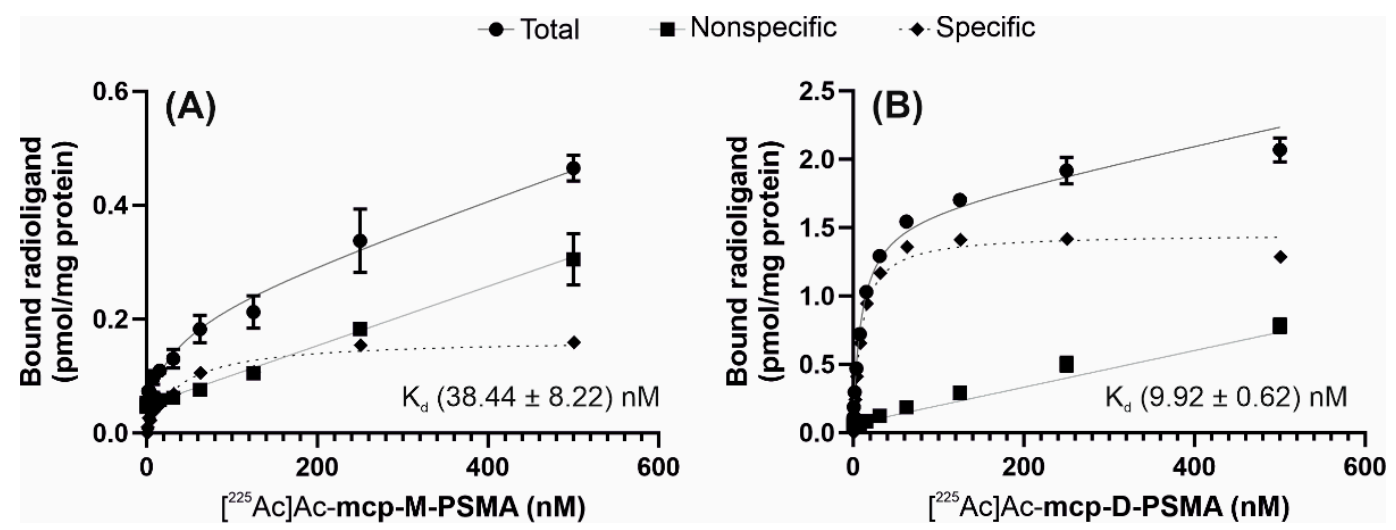

Figure 3. Saturation binding curves for ${ }^{225}$ Ac-labeled mcp-M-PSMA (A) and mcp-D-PSMA (B). Total binding was measured in the absence of and nonspecific binding in the presence of $500 \mu \mathrm{M}$ unlabeled PSMA-617. Specific binding was calculated as the difference between total and nonspecific binding ( $n=3$ for each data point).

\subsection{Cytotoxicity of ${ }^{225}$ Ac-Labeled PSMA Derivatives}

To evaluate the cytotoxicity in vitro induced by $\left[{ }^{225} \mathrm{Ac}\right] \mathrm{Ac}-\mathrm{mcp}-\mathrm{M}-\mathrm{PSMA}$ or $\left[{ }^{225} \mathrm{Ac}\right] \mathrm{Ac}-$ mcp-D-PSMA, LNCaP cells were exposed once for 1 or $4 \mathrm{~h}$, respectively, and the cell number was determined $24 \mathrm{~h}$ after the treatment by DNA staining (Figure 4 ).

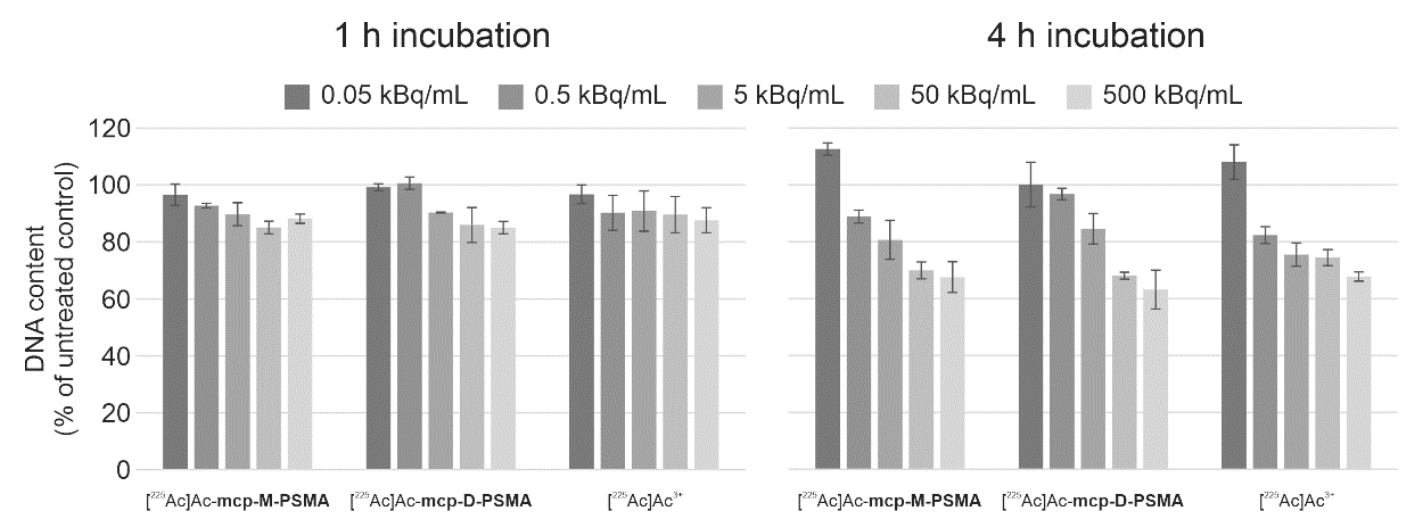

Figure 4. Antiproliferative activity of ${ }^{225}$ Ac-labeled PSMA derivatives compared to the non-targeted activity control. PSMA-expressing LNCaP cells were incubated for 1 or $4 \mathrm{~h}$, respectively, with increasing activity concentrations of [ ${ }^{225}$ Ac]Acmcp-M-PSMA, $\left[{ }^{225} \mathrm{Ac}\right] \mathrm{Ac}-\mathrm{mcp}-\mathrm{D}-\mathrm{PSMA}$ or the non-targeted activity control $\left[{ }^{225} \mathrm{Ac}\right] \mathrm{Ac}^{3+}$, and subsequently supplemented with fresh medium. The DNA fluorescence assay was performed $24 \mathrm{~h}$ after radioactivity removal. 
The relative number of LNCaP cells decreased with increasing radioactive doses and with extended incubation time. Already after $1 \mathrm{~h}$ of exposure, the proliferation rate was reduced by more than $10 \%$ at the second highest dose of $50 \mathrm{kBq} / \mathrm{mL}$. The relative cell number is further decreased by approximately one third at the highest applied dose after $4 \mathrm{~h}$ of exposure to $\left[{ }^{225} \mathrm{Ac}\right] \mathrm{Ac}-\mathbf{m c p}-\mathrm{M}$-PSMA or $\left[{ }^{225} \mathrm{Ac}\right] \mathrm{Ac}-\mathbf{m c p}-\mathrm{D}-\mathrm{PSMA}$. However, the incubation with $\left[{ }^{225} \mathrm{Ac}\right] \mathrm{Ac}^{3+}$ as non-targeted activity control reduced the proliferation to a similar extent.

To determine whether the antiproliferative activity of the ${ }^{225}$ Ac-labeled PSMA derivatives is associated with triggering programmed cell death pathways, the induction of apoptosis was analyzed by measuring the level of phosphatidylserine exposure on the outer leaflet of the cell membrane using an annexin V based assay (Figure 5). The incubation of human prostate adenocarcinoma cells with the ${ }^{225}$ Ac-labeled PSMA derivatives or with non-targeted $\left[{ }^{225} \mathrm{Ac}\right] \mathrm{Ac}^{3+}$, respectively, resulted in increased staining for exposed phosphatidylserine beginning at $4 \mathrm{~h}$, indicating the induction of apoptosis. The magnitude of annexin $\mathrm{V}$ binding grew steadily until $8 \mathrm{~h}$ owing to more phosphatidylserine exposure by the progression of the cellular apoptotic program. Noteworthy, no appreciable loss of membrane integrity due to secondary necrosis was detected during this period (data not shown). Phosphatidylserine exposure appears dose- and time-dependent, whereas no substantial difference was observed between the treatment with [ $\left.{ }^{225} \mathrm{Ac}\right] \mathrm{Ac}-\mathbf{m c p}-\mathbf{M - P S M A}$, $\left[{ }^{225} \mathrm{Ac}\right]$ Ac-mcp-D-PSMA or non-targeted $\left[{ }^{225} \mathrm{Ac}\right] \mathrm{Ac}^{3+}$. This is in agreement with the data obtained by the proliferation assay and suggests that ${ }^{225} \mathrm{Ac}$-induced cell damage is independent of PSMA targeting. Obviously, $\left[{ }^{225} \mathrm{Ac}\right] \mathrm{Ac}^{3+}$ added directly to the cell culture media appears to be as effective as the specifically binding ${ }^{225}$ Ac-labeled ligands. However, these observations originate from the experimental design. Under the static (flow-free) conditions of a two-dimensional cell culture in a simple petri dish, molecular targeting and cell binding via one or two PSMA-binding motifs plays no-or just a negligible-role for the efficacy of $\alpha$ particles coming from ${ }^{225} \mathrm{Ac}$ and the direct radiotoxic effects of $\left[{ }^{225} \mathrm{Ac}\right] \mathrm{Ac}-\mathbf{m c p}-\mathbf{M}-\mathbf{P S M A}$, $\left[{ }^{225} \mathrm{Ac}\right] \mathrm{Ac}-\mathbf{m c p}-\mathrm{D}-\mathrm{PSMA}$ and non-targeted $\left[{ }^{225} \mathrm{Ac}\right] \mathrm{Ac}^{3+}$ are comparable.

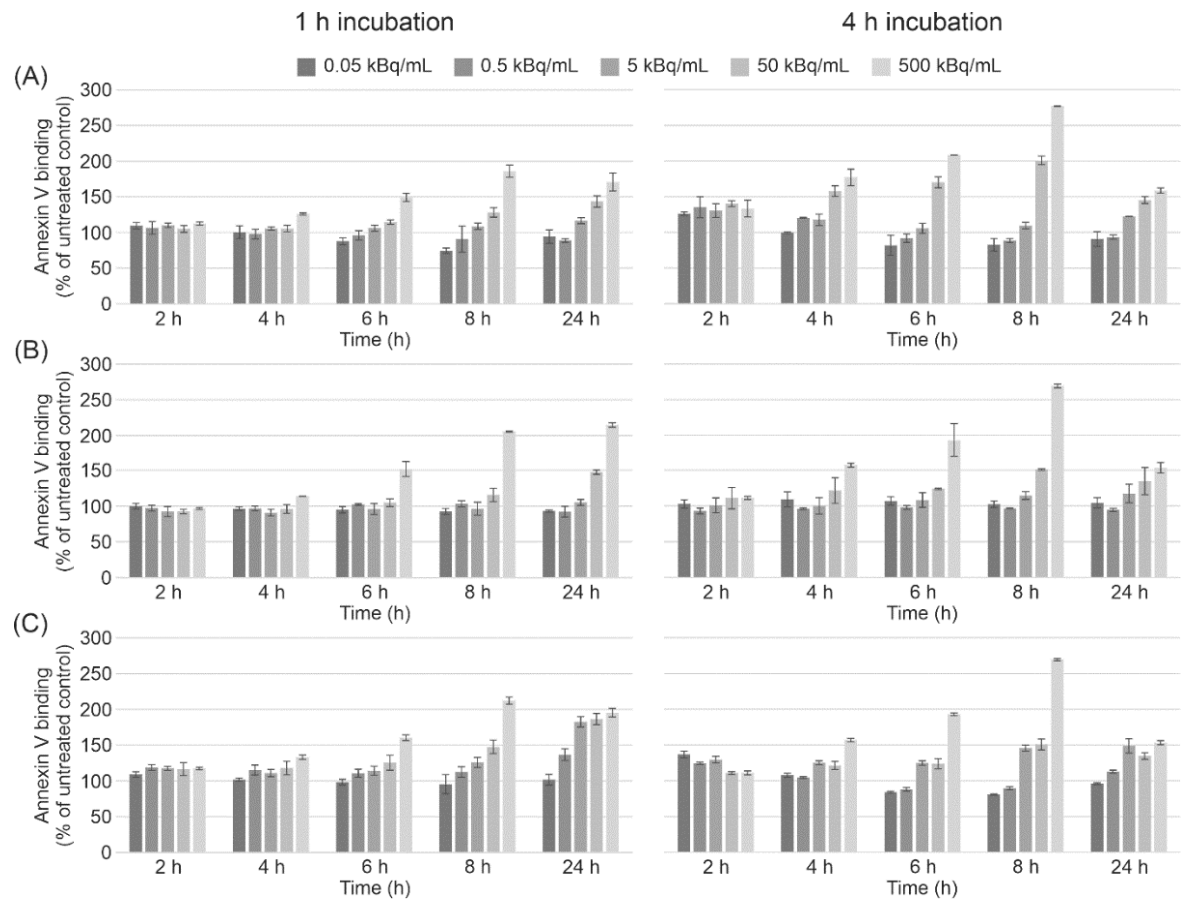

Figure 5. Kinetic profile of phosphatidylserine exposure on apoptotic LNCaP cells as a response to the treatment with ${ }^{225}$ Ac-labeled PSMA derivatives. The human prostate adenocarcinoma cells were incubated for 1 or $4 \mathrm{~h}$, respectively, with increasing activity concentrations of $\left[{ }^{225}\right.$ Ac] Ac-mcp-M-PSMA (A), $\left[{ }^{225}\right.$ Ac]Ac-mcp-D-PSMA (B) or non-targeted $\left[{ }^{225} \mathrm{Ac}\right] \mathrm{Ac}^{3+}(\mathbf{C})$, and subsequently supplemented with fresh medium. The real-time, bioluminescent annexin $\mathrm{V}$ assay was performed 2, 4, 6, 8 and $24 \mathrm{~h}$ after radioactivity removal. 


\subsection{Clonogenicity in Response to the Incubation with ${ }^{225}$ Ac-Labeled PSMA Derivatives}

A colony formation assay, performed to assess the clonogenic survival of LNCaP cells after treatment with increasing activity $(0.05 \mathrm{kBq}-50 \mathrm{kBq} / \mathrm{mL})$ of $\left[{ }^{225} \mathrm{Ac}\right] \mathrm{Ac}-\mathbf{m c p}-\mathrm{M}-$ PSMA or $\left[{ }^{225} \mathrm{Ac}\right]$ Ac-mcp-D-PSMA, respectively, revealed a time- and dose-dependent decrease in colony-forming cells (see SI, Table S1). Furthermore, notable differences in the formation of colonies upon incubation with PSMA-targeted ([ ${ }^{225}$ Ac]Ac-mcp-M-PSMA and $\left[{ }^{225} \mathrm{Ac}\right] \mathrm{Ac}$-mcp-D-PSMA) and $\left[{ }^{225} \mathrm{Ac}\right] \mathrm{Ac}^{3+}$ as non-targeted activity control were observed. The one-hour treatment with $5 \mathrm{kBq} / \mathrm{mL}$ resulted in $19.4 \%$ of the reference amount of colonies for the monomeric PSMA derivative and in $3.1 \%$ for the dimeric counterpart. In contrast, the clonogenic cell survival was higher (32.9\%) after the treatment with the identical activity concentration of non-targeted $\left[{ }^{225} \mathrm{Ac}\right] \mathrm{Ac}^{3+}$. Noteworthy, in terms of the cytotoxic capacity, the dimeric $\left[{ }^{225} \mathrm{Ac}\right] \mathrm{Ac}-\mathrm{mcp}$-D-PSMA is superior to the monomeric $\left[{ }^{225} \mathrm{Ac}\right]$ Ac-mcp-M-PSMA at all time points and even at low activity levels (Figure 6).

\section{$1 \mathrm{~h}$}

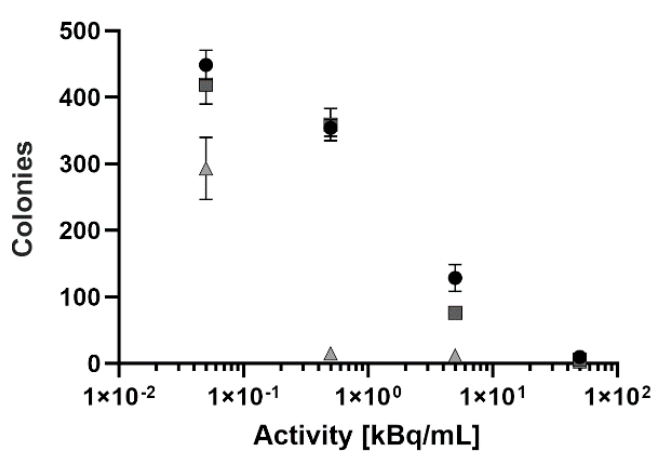

- ${ }^{225} \mathrm{Ac}^{2} \mathrm{Ac}^{3+}$

- $\left.{ }^{225} \mathrm{Ac}\right] \mathrm{AC}-\mathrm{mCP}-\mathrm{M}-\mathrm{PSM} A$

$\left.\triangle{ }^{225} \mathrm{Ac}\right] A \mathrm{~A}-\mathrm{m}$ CP-D-PSMA
$4 \mathrm{~h}$

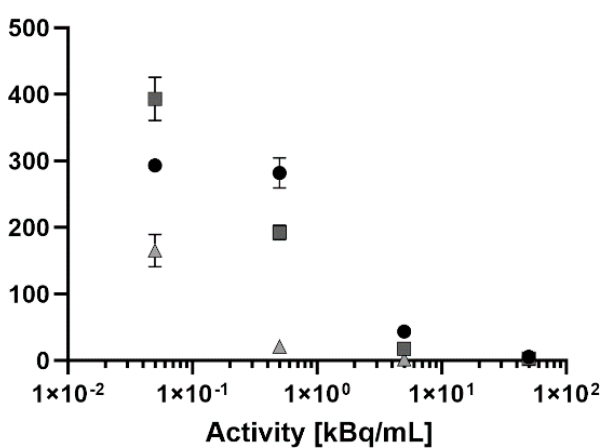

Figure 6. Colony-forming assay using LNCaP cells, indicating the ability of both ${ }^{225}$ Ac-labeled PSMA ligands to inhibit cell proliferation and colony formation in a time- and dose-dependent manner. The human prostate adenocarcinoma cells were incubated for 1 or $4 \mathrm{~h}$, respectively, with increasing activity concentrations of $\left[{ }^{225}\right.$ Ac]Ac-mcp-M-PSMA, $\left[{ }^{225}\right.$ Ac]Ac-mcp-D-PSMA or $\left[{ }^{225}\right.$ Ac $] \mathrm{Ac}^{3+}$ as nontargeted activity control. After the indicated treatment time, cells were supplemented with fresh medium and cultures were incubated for 8 days to allow colony growth.

Microscopic images of the crystal violet stained well plates underline the cytotoxic potency of both ${ }^{225} \mathrm{Ac}$-radioconjugates and highlight the increased cell-killing capacity of the dimeric complex compared to the monomeric ligand (Figure 7). Nearly no colonies were detected after a one-hour exposure of the human prostate adenocarcinoma cells with $50 \mathrm{kBq} / \mathrm{mL}\left[{ }^{225} \mathrm{Ac}\right] \mathrm{Ac}-\mathrm{mcp}-\mathrm{D}-\mathrm{PSMA}$. The treatment of LNCaP cells with 5 and $50 \mathrm{kBq} / \mathrm{mL}$ $\left[{ }^{225}\right.$ Ac]Ac-mcp-D-PSMA, respectively, for $4 \mathrm{~h}$ also resulted in almost $100 \%$ inhibition of colony formation. 
(A)

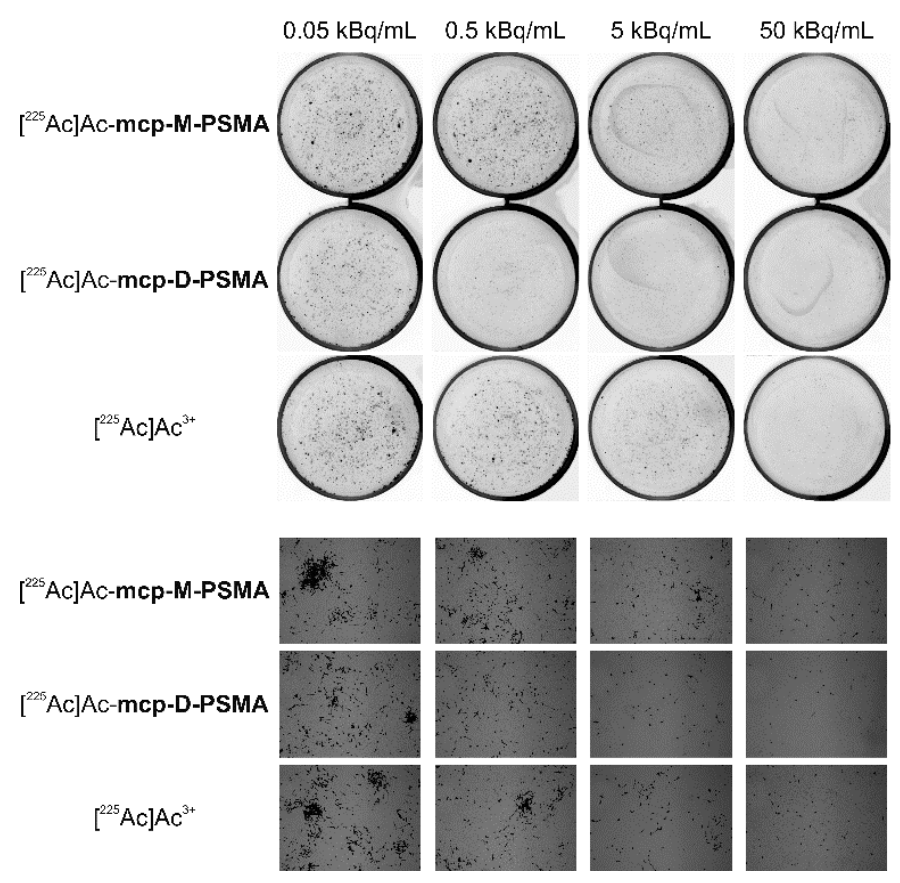

(B)

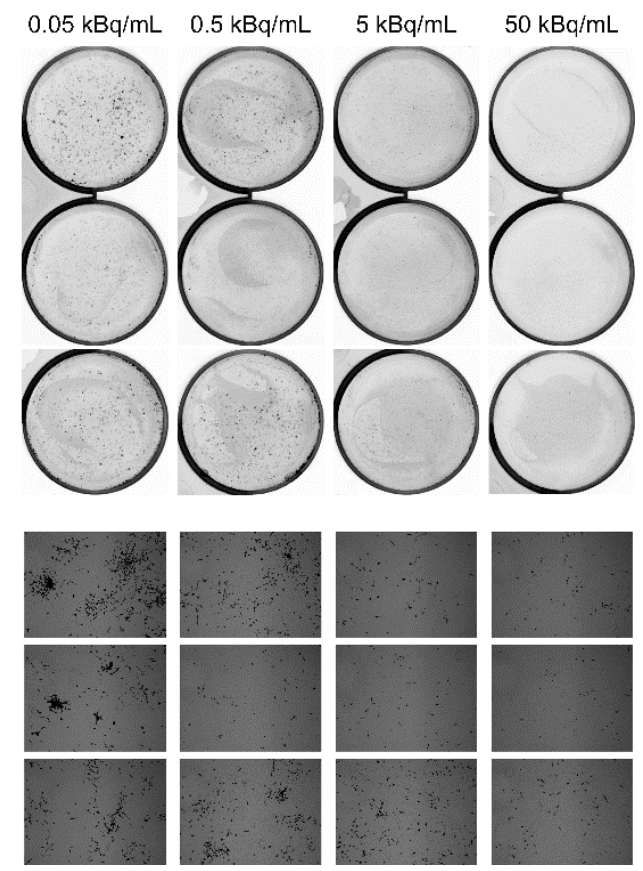

Figure 7. Representative overview photographs and microscopic images of crystal violet stained wells, after colony-forming assay using LNCaP cells, upon exposure to increasing activity concentrations ( $0.05 \mathrm{kBq}-50 \mathrm{kBq} /$ well) of [ $\left.{ }^{225} \mathrm{Ac}\right] \mathrm{Ac}-\mathrm{mcp}-\mathbf{M}$ PSMA and $\left[{ }^{225} \mathrm{Ac}\right] \mathrm{Ac}-\mathbf{m c p}-\mathrm{D}-\mathrm{PSMA}$, compared to $\left[{ }^{225} \mathrm{Ac}\right] \mathrm{Ac}{ }^{3+}$ as non-targeted activity control for $1 \mathrm{~h}(\mathbf{A})$ or $4 \mathrm{~h}(\mathbf{B})$. After the indicated treatment time, cells were supplemented with fresh medium and cultures were incubated for eight days to allow colony growth (magnification: $40 \times$ ).

\subsection{Small Animal Biodistribution Experiments}

The obtained biodistribution data showed similar in vivo behavior for both studied radiotracers $\left[{ }^{225} \mathrm{Ac}\right] \mathrm{Ac}-\mathbf{m c p}-\mathrm{M}-\mathrm{PSMA}$ and $\left[{ }^{225} \mathrm{Ac}\right] \mathrm{Ac}-\mathbf{m c p}-\mathrm{D}-\mathrm{PSMA}$ in LNCaP tumorbearing mice (Figure 8; see Tables S2 and S3 in the SI for quantitative data). The biodistribution data using non-tumor-bearing SCID mice is presented in the SI (Figure S16, Tables S4 and S5).

The organ distribution profile indicates a PSMA-mediated uptake in tissues with documented PSMA expression including kidneys and spleen besides the pathologic radiotracer accumulation in the tumor [36-39]. The highest activity accumulation was found in kidneys at $10 \mathrm{~min}(117.81 \pm 19.86 \% \mathrm{ID} / \mathrm{g}$ vs. $66.01 \pm 7.20 \% \mathrm{ID} / \mathrm{g})$ and $60 \mathrm{~min}(67.84 \pm 23.92 \% \mathrm{ID} / \mathrm{g}$ vs. $103.03 \pm 24.68 \% \mathrm{ID} / \mathrm{g})$ p.i., rapidly decreasing in time $(1.35 \pm 0.26 \% \mathrm{ID} / \mathrm{g}$ vs. $7.17 \pm 1.96 \% \mathrm{ID} / \mathrm{g}$ at $24 \mathrm{~h}$ p.i.) for both compounds. [ $\left.{ }^{225} \mathrm{Ac}\right]$ Ac-mcp-D-PSMA showed longer renal retention during the first $60 \mathrm{~min}$ p.i. compared to $\left[{ }^{225} \mathrm{Ac}\right] \mathrm{Ac}-\mathbf{m c p}-\mathbf{M}-\mathbf{P S M A}$, what was expected due to the difference in molar masses, but also through the binding potential in the proximal tubuli. The renal clearance of both radiotracers from the blood was very fast and the majority of the activity was eliminated from the blood circulation within 60 min post injection. The other excised organs revealed negligible radioactivity uptake except the spleen at early time points. The radioactivity uptake in the spleen $10 \mathrm{~min}$ p.i. differs between the monomeric $(25.05 \pm 10.42 \% \mathrm{ID} / \mathrm{g})$ and the dimeric $(13.42 \pm 6.11 \% \mathrm{ID} / \mathrm{g})$ radioligand. For both ${ }^{225}$ Ac-labeled PSMA derivatives, the spleen uptake is substantially lower after $1 \mathrm{~h}$ p.i. with $2.90 \pm 1.69 \% \mathrm{ID} / \mathrm{g}$ and $4.57 \pm 1.71 \% \mathrm{ID} / \mathrm{g}$, respectively. The observed difference in the spleen uptake $10 \mathrm{~min}$ p.i. originates from the individual blood clearance kinetics of both ligands as underlined by related differences in the kidney accumulation.

The tumor accumulation of $\left[{ }^{225} \mathrm{Ac}\right] \mathrm{Ac}-\mathbf{m c p}-\mathbf{M}-\mathbf{P S M A}$ was higher at 10 and $60 \mathrm{~min}$ p.i. compared to $\left[{ }^{225} \mathrm{Ac}\right] \mathrm{Ac}-\mathrm{mcp}-\mathrm{D}-\mathrm{PSMA}$. The opposite results were observed at $24 \mathrm{~h}$ p.i., where $\left[{ }^{225} \mathrm{Ac}\right]$ Ac-mcp-M-PSMA showed a lower accumulation compared to [ $\left.{ }^{225} \mathrm{Ac}\right] \mathrm{Ac}$ - 
mcp-D-PSMA $(6.78 \pm 0.45 \% \mathrm{ID} / \mathrm{g}$ versus $12.21 \pm 4.31 \% \mathrm{ID} / \mathrm{g})$. Tumor-to-background ratios were favorably high for both tested compounds and increased rapidly with time after administration. Tumor-to-blood ratios at $24 \mathrm{~h}$ p.i. were determined to be 188.42 and 158.11 for [ $\left.{ }^{225} \mathrm{Ac}\right]$ Ac-mcp-M-PSMA and $\left[{ }^{225} \mathrm{Ac}\right]$ Ac-mcp-D-PSMA, respectively, and tumor-tomuscle ratios at $24 \mathrm{~h}$ p.i. were calculated as 310.82 and 275.77. Overall, the biodistribution pattern of $\left[{ }^{225} \mathrm{Ac}\right] \mathrm{Ac}-\mathrm{mcp}-\mathrm{M}-\mathrm{PSMA}$ and $\left[{ }^{225} \mathrm{Ac}\right] \mathrm{Ac}-\mathbf{m c p}-\mathrm{D}-\mathrm{PSMA}$ is in accordance with previously published results for [ $\left.{ }^{177} \mathrm{Lu}\right] \mathrm{Lu}-\mathrm{PSMA}-617$ or $\left[{ }^{57} \mathrm{Co}\right] \mathrm{Co}-\mathrm{PSMA}-617[40,41]$ as well as with recent data for other small molecules targeting PSMA [27,39,42,43].

(A)

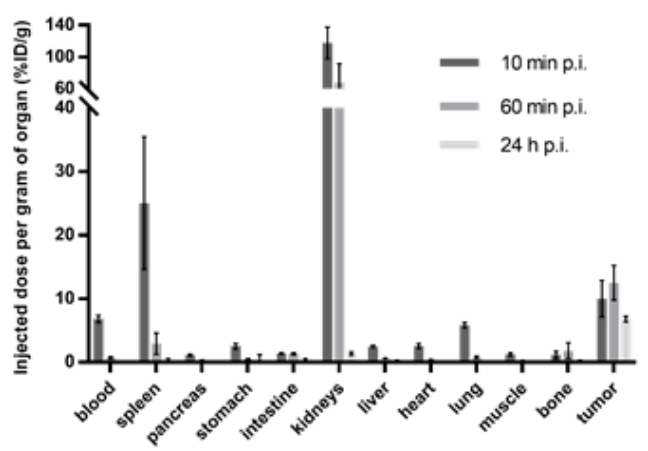

(B)

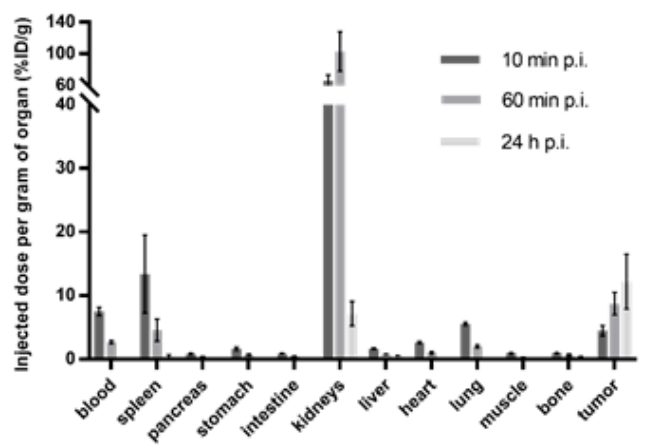

Figure 8. Biodistribution of $\left[{ }^{225} \mathrm{Ac}\right] \mathrm{Ac}-\mathbf{m c p}-\mathrm{M}-\mathrm{PSMA}$ (A) and $\left[{ }^{225} \mathrm{Ac}\right] \mathrm{Ac}-\mathbf{m c p}-\mathrm{D}-\mathrm{PSMA}$ (B) using LNCaP tumor-bearing SCID mice $10 \mathrm{~min}, 60 \mathrm{~min}$ and $24 \mathrm{~h}$ p.i. The data are presented as the mean of the percentage of injected dose per gram of organ \pm standard deviation $(n=4)$.

\section{Materials and Methods}

\subsection{Chemistry}

All chemicals were purchased from commercial suppliers and used without further purification. NMR spectra of all synthesized compounds were carried out on an Agilent DD2-400 MHz NMR or Agilent DD2-600 MHz NMR spectrometer with ProbeOne. All chemical shifts of ${ }^{1} \mathrm{H}$ and ${ }^{13} \mathrm{C}$ signals were reported in parts per million using TMS as internal standard at $25^{\circ} \mathrm{C}$ and all spectra were calibrated using the respective solvent signal. Mass spectra were recorded on an Advion ExpressIon CMS or Xevo T-QS (Waters) using electrospray ionization. TLC analyses for reaction control were performed on Merck Silica Gel $60 \mathrm{~F}_{254}$ TLC plates and visualized using UV light. Analytical HPLC was performed on VWR Hitachi with an Agilent C18 column (Agilent Zorbax 300SB-C18, $100 \mathrm{~mm}$ $\times 4.6 \mathrm{~mm})$ and acetonitrile/water $(0.1 \%$ TFA each) as mobile phase. Chromatographic separations were performed using automated flash column chromatography on Isolera Four (Biotage) using silica gel cartridges (SNAP KP-Sil; $10 \mathrm{~g}$ or $25 \mathrm{~g}$ ) and reversed phase HPLC system Knauer Azura with Zorbax 300SB-C18 semi-preparative column and acetonitrile/water ( $0.1 \%$ TFA each) as mobile phase. Starting materials such as anhydrous solvents, dimethyl 4-hydroxypyridine-2,6-dicarboxylate (TCI Europe) and 4,13-diaza-18-crown-6 (Merck) were purchased and used as received. Methyl 6-(chloromethyl)picolinate was prepared according to the literature [44].

\subsubsection{Methyl 6-((1,4,10,13-tetraoxa-7,16-diazacyclooctadecan-7-yl)methyl)picolinate $\mathbf{1}$}

4,13-Diaza-18-crown-6 (K2.2, $900 \mathrm{mg}, 3.43 \mathrm{mmol}$ ) and N,N-diisopropylethylamine (399 mg, $3.09 \mathrm{mmol})$ were dissolved in anhydrous acetonitrile $(30 \mathrm{~mL})$ and brought to $80^{\circ} \mathrm{C}$. Methyl 6-(chloromethyl)picolinate $(450 \mathrm{mg}, 2.42 \mathrm{mmol})$ dissolved in anhydrous acetonitrile $(12 \mathrm{~mL})$ was added dropwise by a syringe pump over a period of $5 \mathrm{~h}$ and the resulting mixture was refluxed overnight. After cooling to rt, the solids were removed by filtration and the solvent was removed. The crude product was purified via column chromatography (ethyl acetate/ethanol $+1 \%$ triethylamine) to obtain compound $\mathbf{1}$ as slightly yellow solid (580 $\mathrm{mg}$, $41 \%$ ). $R_{f}=0.12$ (ethyl acetate/ethanol/triethylamine $=10: 15: 0.5$ ) and the bis-functionalized by- 
product dimethyl 6,6'-((1,4,10,13-tetraoxa-7,16-diazacyclooctadecane-7,16-diyl)bis(methylene)) dipicolinate (183 mg; $\left.\mathrm{R}_{f}=0.29\right) ;{ }^{1} \mathrm{H}$ NMR $\left(600 \mathrm{MHz}, \mathrm{CDCl}_{3}\right): \delta=2.75-2.85\left(\mathrm{~m}, 4 \mathrm{H}, \mathrm{NCH}_{2}\right)$, 2.90-2.99 (m, 4H, NCH $)_{2}, 3.40-3.60\left(\mathrm{~m}, 12 \mathrm{H}, \mathrm{OCH}_{2}\right), 3.70-3.77\left(\mathrm{~m}, 4 \mathrm{H}, \mathrm{OCH}_{2}\right), 3.86(\mathrm{~s}, 2 \mathrm{H}$, $\left.\mathrm{ArCH}_{2}\right), 3.96\left(\mathrm{~s}, 3 \mathrm{H}, \mathrm{CH}_{3}\right), 7.87-8.00\left(\mathrm{~m}, 3 \mathrm{H}, \mathrm{H}_{\mathrm{Ar}}\right) \mathrm{ppm} ;{ }^{13} \mathrm{C} \mathrm{NMR}\left(151 \mathrm{MHz}, \mathrm{CDCl}_{3}\right): \delta=49.1$ $\left(\mathrm{NCH}_{2}\right), 52.9\left(\mathrm{CH}_{3}\right), 56.2\left(\mathrm{NCH}_{2}\right), 60.0\left(\mathrm{ArCH}_{2}\right), 68.6\left(\mathrm{OCH}_{2}\right), 68.9\left(\mathrm{OCH}_{2}\right), 70.2\left(\mathrm{OCH}_{2}\right), 70.3$ $\left(\mathrm{OCH}_{2}\right), 123.6\left(\mathrm{CH}_{\mathrm{Ar}}\right), 127.0\left(\mathrm{CH}_{\mathrm{Ar}}\right), 138.0\left(\mathrm{CH}_{\mathrm{Ar}}\right), 146.8\left(\mathrm{C}_{\mathrm{Ar}}\right), 161.4\left(\mathrm{C}_{\mathrm{Ar}}\right), 166.0(\mathrm{C}=\mathrm{O}) \mathrm{ppm}$; MS (ESI+): $m / z=412(100)[\mathrm{M}+\mathrm{H}]^{+}, 434(63)[\mathrm{M}+\mathrm{Na}]^{+}$. All original spectra can be found in the SI, Figure S7.

3.1.2. Methyl 6-((16-((6-(methoxycarbonyl)pyridin-2-yl)methyl)-1,4,10,13-tetraoxa-7,16diazacyclooctadecan-7-yl)methyl)-4-(prop-2-yn-1-yloxy)picolinate 2

Compound SI-III (143 mg, $0.60 \mathrm{mmol})$, compound $1(204 \mathrm{mg}, 0.50 \mathrm{mmol})$ and $\mathrm{N}, \mathrm{N}$ diisopropylethylamine $(107 \mu \mathrm{L}, 0.60 \mathrm{mmol})$ were dissolved in anhydrous acetonitrile $(10 \mathrm{~mL})$ and the mixture was refluxed overnight. After cooling to rt and TLC control, the solvent was removed and the crude product was purified via column chromatography (ethyl acetate/ethanol $+1 \%$ triethylamine) to obtain compound 2 as colorless oil (214 $\mathrm{mg}$, $70 \%) . \quad \mathrm{R}_{f}=0.26$ (ethyl acetate/ ethanol $\left.=2: 3\right) ;{ }^{1} \mathrm{H}$ NMR $\left(600 \mathrm{MHz}, \mathrm{CDCl}_{3}\right): \delta=2.59$ (br. s, $1 \mathrm{H}, \equiv \mathrm{CH}), 2.86$ (br. s, $\left.8 \mathrm{H}, \mathrm{NCH}_{2}\right), 3.52-3.68\left(\mathrm{~m}, 12 \mathrm{H}, \mathrm{OCH}_{2}\right), 3.87-4.01(\mathrm{~m}, 8 \mathrm{H}$, $\left.2 \times \mathrm{CH}_{3}+\mathrm{ArCH}_{2}\right), 4.78$ (br. s, $\left.2 \mathrm{H}, \mathrm{ArCH}_{2}\right), 7.47-7.60\left(\mathrm{~m}, 2 \mathrm{H}, \mathrm{H}_{\mathrm{Ar}}\right), 7.76\left(\mathrm{t},{ }^{3} \mathrm{~J}=7.2 \mathrm{~Hz}, 1 \mathrm{H}\right.$, $\left.\mathrm{H}_{\mathrm{Ar}}\right), 7.87$ (br. s, $\left.1 \mathrm{H}, \mathrm{H}_{\mathrm{Ar}}\right), 7.94\left(\mathrm{~d},{ }^{3} \mathrm{~J}=7.2 \mathrm{~Hz}, 1 \mathrm{H}, \mathrm{H}_{\mathrm{Ar}}\right) \mathrm{ppm} ;{ }^{13} \mathrm{C} \mathrm{NMR}\left(151 \mathrm{MHz}, \mathrm{CDCl}_{3}\right)$ : $\delta=53.0\left(\mathrm{CH}_{3}\right), 53.1\left(\mathrm{CH}_{3}\right), 54.5\left(\mathrm{NCH}_{2}\right), 54.6\left(\mathrm{NCH}_{2}\right), 56.0\left(\mathrm{OCH}_{2}\right), 61.5$ (br. s, $\left.\mathrm{OCH}_{2}\right), 69.9$ (br. s, $\left.\mathrm{OCH}_{2}\right), 70.8\left(\mathrm{OCH}_{2}\right), 70.9\left(\mathrm{OCH}_{2}\right), 76.9(\equiv \mathrm{C}), 77.2(\equiv \mathrm{CH}), 110.9\left(\mathrm{CH}_{\mathrm{Ar}}\right), 112.0\left(\mathrm{CH}_{\mathrm{Ar}}\right)$, 123.6 $\left(\mathrm{CH}_{\mathrm{Ar}}\right), 126.4\left(\mathrm{CH}_{\mathrm{Ar}}\right), 137.5\left(\mathrm{CH}_{\mathrm{Ar}}\right), 147.2\left(\mathrm{C}_{\mathrm{Ar}}\right), 148.9\left(\mathrm{C}_{\mathrm{Ar}}\right), 161.5$ (br. s, $\left.\mathrm{C}_{\mathrm{Ar}}\right), 163.5$ (br. s, $\left.\mathrm{C}_{\mathrm{Ar}}\right), 165.3\left(\mathrm{C}_{\mathrm{Ar}}\right), 165.8(\mathrm{C}=\mathrm{O}), 166.0(\mathrm{C}=\mathrm{O}) \mathrm{ppm}$; MS (ESI+): $\mathrm{m} / \mathrm{z}=615(100)[\mathrm{M}+\mathrm{H}]^{+}$, $636(39)[\mathrm{M}+\mathrm{Na}]^{+}$. All original spectra can be found in the SI, Figure S8.

3.1.3. Dimethyl 6,6'-((1,4,10,13-tetraoxa-7,16-diazacyclooctadecane-7,16diyl)bis(methylene))bis(4-(prop-2-yn-1-yloxy)picolinate) 3

4,13-Diaza-18-crown-6 (K2.2, 100 mg, $0.38 \mathrm{mmol})$, compound SI-III (228 mg, $0.95 \mathrm{mmol}$ ) and $N, N$-diisopropylethylamine $(148 \mathrm{mg}, 1.14 \mathrm{mmol})$ were dissolved in anhydrous acetonitrile $(8 \mathrm{~mL})$ and refluxed overnight. After cooling to $\mathrm{rt}$, the solids were removed by filtration and the solvent was removed. The crude product was purified via column chromatography (ethyl acetate/ethanol $+1 \%$ triethylamine) to obtain compound 3 as slightly yellow solid (160 mg, $63 \%) . \mathrm{R}_{f}=0.35$ (ethyl acetate/ethanol/triethylamine $\left.=10: 15: 0.5\right) ;{ }^{1} \mathrm{H} \mathrm{NMR}\left(600 \mathrm{MHz}, \mathrm{CDCl}_{3}\right)$ : $\delta=2.59$ (br. s, $2 \mathrm{H}, \equiv \mathrm{CH}), 2.85$ (br. s, $\left.8 \mathrm{H}, \mathrm{NCH}_{2}\right), 3.52-3.68\left(\mathrm{~m}, 12 \mathrm{H}, \mathrm{OCH}_{2}\right), 3.84-4.02(\mathrm{~m}, 10 \mathrm{H}$, $\left.2 \times \mathrm{CH}_{3}+\mathrm{NCH}_{2}\right), 4.78\left(\mathrm{~s}, 4 \mathrm{H}, \mathrm{ArCH}_{2}\right), 7.46-7.61\left(\mathrm{~m}, 4 \mathrm{H}, \mathrm{H}_{\mathrm{Ar}}\right) \mathrm{ppm} ;{ }^{13} \mathrm{C} \mathrm{NMR}(151 \mathrm{MHz}$, $\left.\mathrm{CDCl}_{3}\right): \delta=53.1\left(\mathrm{CH}_{3}\right), 54.5\left(\mathrm{NCH}_{2}\right), 54.6\left(\mathrm{NCH}_{2}\right), 56.0\left(\mathrm{OCH}_{2}\right), 61.5\left(\right.$ br. s, $\left.\mathrm{OCH}_{2}\right), 69.9$ (br. s, $\left.\mathrm{OCH}_{2}\right), 70.9\left(\mathrm{OCH}_{2}\right), 76.9(\equiv \mathrm{C}), 77.2(\equiv \mathrm{CH}), 110.9\left(\mathrm{CH}_{\mathrm{Ar}}\right), 112.1\left(\mathrm{CH}_{\mathrm{Ar}}\right), 148.9\left(\mathrm{C}_{\mathrm{Ar}}\right)$, 163.6 (br. s, $\left.\mathrm{C}_{\mathrm{Ar}}\right), 165.3\left(\mathrm{C}_{\mathrm{Ar}}\right), 165.8(\mathrm{C}=\mathrm{O}) \mathrm{ppm}$; MS (ESI+): $\mathrm{m} / z=669(100)[\mathrm{M}+\mathrm{H}]^{+}, 691(30)$ $[\mathrm{M}+\mathrm{Na}]^{+}$. All original spectra can be found in the SI, Figure S9.

3.1.4. 6-((16-((6-Carboxypyridin-2-yl)methyl)-1,4,10,13-tetraoxa-7,16diazacyclooctadecan-7-yl)methyl)-4-(prop-2-yn-1-yloxy)picolinic acid mcp-M-click

Compound $2(40 \mathrm{mg}, 0.07 \mathrm{mmol})$ was dissolved in a $1 / 1$ mixture of methanol and water $(5 \mathrm{~mL})$ and $\mathrm{LiOH}(10 \mathrm{mg}, 0.42 \mathrm{mmol})$ was added. The resulting mixture was stirred at $50{ }^{\circ} \mathrm{C}$ for $4 \mathrm{~h}$. Afterwards, the solvent was removed and purification was done via semipreparative HPLC (eluent: $15 \% \rightarrow 35 \% \mathrm{ACN}+0.1 \%$ TFA in $35 \mathrm{~min}$, flow rate $=6 \mathrm{~mL} / \mathrm{min}$, $\mathrm{t}_{\mathrm{R}}=10 \mathrm{~min}$; Agilent Zorbax 300SB-C18, $\left.9.4 \mathrm{~mm} \times 250 \mathrm{~mm}\right)$ to yield mcp-M-click as colorless solid (30 mg, 76\%); MS (ESI+): $m / z=294(100)[(\mathrm{M}+2 \mathrm{H}) / 2]^{+}, 587(47)[\mathrm{M}+\mathrm{H}]^{+}$, 609 (17) $[\mathrm{M}+\mathrm{Na}]^{+}$. All original spectra can be found in the SI, Figure S10. 
3.1.5. 6,6'-((1,4,10,13-Tetraoxa-7,16-diazacyclooctadecane-7,16-diyl)bis(methylene))bis(4(prop-2-yn-1-yloxy)picolinic acid) mcp-D-click

Compound 3 (100 $\mathrm{mg}, 0.15 \mathrm{mmol})$ was dissolved in a 1/1 mixture of methanol and water $(5 \mathrm{~mL})$ and $\mathrm{LiOH}(19 \mathrm{mg}, 0.9 \mathrm{mmol})$ was added. The resulting mixture was stirred at $50{ }^{\circ} \mathrm{C}$ for $4 \mathrm{~h}$. Afterwards, the solvent was removed and purification was done via semipreparative HPLC (eluent: $15 \% \rightarrow 35 \% \mathrm{ACN}+0.1 \%$ TFA in $35 \mathrm{~min}$, flow rate $=6 \mathrm{~mL} / \mathrm{min}$, $\mathrm{t}_{\mathrm{R}}=16 \mathrm{~min}$, Agilent Zorbax 300SB-C18, $9.4 \mathrm{~mm} \times 250 \mathrm{~mm}$ ) to yield mcp-D-click as colorless oil (90 mg, quant.); MS (ESI+): $m / z=321(100)[(\mathrm{M}+2 \mathrm{H}) / 2]^{+}, 641(50)[\mathrm{M}+\mathrm{H}]^{+}$, $663(10)[\mathrm{M}+\mathrm{Na}]^{+}$. All original spectra can be found in the SI, Figure S11.

3.1.6. (3RS,10RS,14S)-1-((1s,4S)-4-((5-(4-(((2-Carboxy-6-((16-((6-carboxypyridin-2yl)methyl)-1,4,10,13-tetraoxa-7,16-diazacyclooctadecan-7-yl)methyl)pyridin-4yl)oxy)methyl)-1H-1,2,3-triazol-1-yl)pentanamido)methyl)cyclohexyl)-3-(naphthalen-2ylmethyl)-1,4,12-trioxo-2,5,11,13-tetraazahexadecane-10,14,16-tricarboxylic acid mcp-M-PSMA

The chelator mcp-M-click (20 mg, $34 \mu \mathrm{mol})$, PSMA-N $_{3}(20 \mathrm{mg}, 25 \mu \mathrm{mol})$, tetrakis (acetonitrile)copper(I) hexafluorophosphate $(1.9 \mathrm{mg}, 0.5 \mu \mathrm{mol})$ and tris[(1-benzyl- $1 \mathrm{H}$ 1,2,3-triazol-4-yl)methyl]amine $(2.7 \mathrm{mg}, 0.5 \mu \mathrm{mol})$ were dissolved in anhydrous $N, N$ dimethylformamide $(2 \mathrm{~mL})$ and stirred at room temperature overnight. Afterwards, the solvent was removed and the crude product was purified by semi-preparative HPLC (eluent: $15 \% \rightarrow 40 \% \mathrm{ACN}+0.1 \%$ TFA in $35 \mathrm{~min}$, flow rate $=6 \mathrm{~mL} / \mathrm{min}, \mathrm{t}_{\mathrm{R}}=21 \mathrm{~min}$, Agilent Zorbax 300SB-C18, $9.4 \mathrm{~mm} \times 250 \mathrm{~mm})$ to yield mcp-M-PSMA as colorless product $(8.5 \mathrm{mg}$, $18 \%) ; \mathrm{MS}(\mathrm{ESI}+): m / z=456(24)[(\mathrm{M}+3 \mathrm{H}) / 3]^{+}, 684(100)[(\mathrm{M}+2 \mathrm{H}) / 2]^{+}, 1367(18)[\mathrm{M}+\mathrm{H}]^{+}$ (see SI, Figure S12).

\subsubsection{Bis-Functionalized PSMA Conjugate mcp-D-PSMA}

The chelator mcp-D-click (20 mg, $31 \mu \mathrm{mol})$, PSMA-N 3 (46 mg, $58 \mu \mathrm{mol})$, tetrakis (acetonitrile)copper(I) hexafluorophosphate $(2.2 \mathrm{mg}, 0.6 \mu \mathrm{mol})$ and tris[(1-benzyl- $1 \mathrm{H}_{-}$ 1,2,3-triazol-4-yl)methyl]amine $(3.2 \mathrm{mg}, 0.6 \mu \mathrm{mol})$ were dissolved in anhydrous $N, N$ dimethylformamide $(2 \mathrm{~mL})$ and stirred at room temperature overnight. Afterwards, the solvent was removed and the crude product was purified by semi-preparative HPLC (eluent: $25 \% \rightarrow 80 \% \mathrm{ACN}+0.1 \%$ TFA in $35 \mathrm{~min}$, flow rate $=6 \mathrm{~mL} / \mathrm{min}, \mathrm{t}_{\mathrm{R}}=10 \mathrm{~min}$, Agilent Zorbax 300SB-C18, $9.4 \mathrm{~mm} \times 250 \mathrm{~mm})$ to yield mcp-D-PSMA as colorless product $(6.5 \mathrm{mg}$, $10 \%)$; MS (ESI+): $m / z=735(100)[(\mathrm{M}+3 \mathrm{H}) / 3]^{+}, 1102(11)[(\mathrm{M}+2 \mathrm{H}) / 2]^{+}$(see SI, Figure S13).

\subsection{Radiolabeling}

Actinium-225 was purchased as a $0.1 \mathrm{M} \mathrm{HCl}$ solution from ITM Munich and used without purification. Stem solutions of all ligands were prepared in concentrations of $10^{-2}$ $\mathrm{M}$ and diluted to $10^{-6} \mathrm{M}$ using $0.2 \mathrm{M}$ ammonium acetate buffer at $\mathrm{pH} 6$. For concentrationdependent labeling experiments, $10 \mu \mathrm{L}$ of each ligand stem solution was incubated with $100 \mathrm{kBq}$ of actinium-225 (1-5 $\mu \mathrm{L})$ and the total volume was adjusted to $100 \mu \mathrm{L}$ with $0.2 \mathrm{M}$ ammonium acetate buffer at $\mathrm{pH}$ 6. For stability analyses, $50 \mu \mathrm{L}$ of the buffer volume were replaced by $50 \mu \mathrm{L}$ of $0.2 \mathrm{M}$ ascorbic acid or $50 \mu \mathrm{L}$ of 2,5-dihydroxy benzoic acid, respectively. Labeling for cell-binding studies was performed using $1.5 \mathrm{MBq}$ of actinium-225 and 4 nmol of the respective PSMA ligand in a total volume of $400 \mu \mathrm{L}$ adjusted with $0.2 \mathrm{M}$ ammonium acetate buffer at $\mathrm{pH}$ 6. Radiolabeling for cell survival studies and all in vivo experiments were performed using $1.5 \mathrm{MBq}$ of actinium-225 and $3.3 \mathrm{nmol}$ of the respective ligand.

All samples were incubated for one hour at room temperature and analyzed afterward. TLC analyses were carried out in two different systems, normal phase on silica plates in $50 \mathrm{mM}$ EDTA solution ( $\mathrm{pH} 7$ ) and reversed-phase on Alugram RP-CN in acetonitrile/water (7/3). TLC plates were imaged using a phosphoimager Amersham Typhoon 5 Scanner (Cytiva Europe $\mathrm{GmbH}$, Freiburg, Germany) after a decay time of at least $7 \mathrm{~h}$. Analytical HPLC was performed using a Jasco HPLC system with RITA analyzer (Elysia-raytest $\mathrm{GmbH}$, Straubenhardt, Germany) for gamma detection on a Phenomenex Phenyl-Hexyl 
column in water/acetonitrile (+ 0.1\% TFA). Radioactivity was measured in Isomed 2100 dose calibrator. Low radioactivity count rates were determined in Isomed 2160 sodium iodide detector. More precise measurements and nuclide identification were carried out on an activity- and efficiency-calibrated HPGe detector CryoPulse 5 (Canberra).

\subsection{Cell Culture}

The human prostate adenocarcinoma cell line LNCaP was obtained from the CLS Cell Lines Service (\#300265, CLS Cell Lines Service GmbH, Eppelheim, Germany) and cultured in RPMI-1640 medium (Thermo Fisher Scientific, Waltham, MA, USA) supplemented with $10 \%$ fetal calf serum (FCS, Merck KGaA, Darmstadt, Germany). Cells were grown in a humidified atmosphere of $95 \%$ air $/ 5 \% \mathrm{CO}_{2}$ at $37{ }^{\circ} \mathrm{C}$. For harvesting, counting and sub-cultivation, culture media was removed and cells were washed three times with PBS (Merck KGaA, Darmstadt, Germany). After the addition of 1\% trypsin-EDTA (Merck $\mathrm{KGaA}$, Darmstadt, Germany), cells were incubated for $5 \mathrm{~min}$ at $37^{\circ} \mathrm{C}$ for detachment from the bottom of the culture flask. Then, culture media was added and cell suspension was transferred into conical centrifuge tubes and spun down for $5 \mathrm{~min}$ at $200 \times \mathrm{g}$ and room temperature. The cell pellet was resuspended in culture media and the cell number, as well as viability, was determined using a CASY cell counter (Roche Diagnostics GmbH, Penzberg, Germany) according to the manufacturer's protocol.

\subsection{Protein Determination}

Protein concentration was determined with the DC Protein Assay (Bio-Rad Laboratories $\mathrm{GmbH}$, Feldkirchen, Germany) according to the manufacturer's microplate assay protocol using bovine serum albumin as a protein standard.

\subsection{Gel Electrophoresis and Western Blot Analysis}

Denaturing sodium dodecyl sulfate-polyacrylamide gel electrophoresis (SDS-PAGE) was performed according to a standard protocol [45]. For each gel, the PageRuler Plus Prestained Protein Ladder (Thermo Fisher Scientific, Waltham, MA, USA) was used as size standard.

LNCaP cell lysates were prepared by addition of $1 \mathrm{~mL}$ of radioimmunoprecipitation assay (RIPA) cell lysis buffer (G-Biosciences, St. Louis, MO, USA) with EDTA-free protease and phosphatase inhibitor cocktail (Thermo Fisher Scientific, Waltham, MA, USA) and $25 \mathrm{U}$ endonuclease (Thermo Fisher Scientific, Waltham, MA, USA). After resuspension and incubation on ice for at least $15 \mathrm{~min}$, cell lysates were centrifuged at $14,000 \times \mathrm{g}$ and $4{ }^{\circ} \mathrm{C}$ for $20 \mathrm{~min}$. Equal protein amounts $(10 \mu \mathrm{g})$ of the supernatants were separated on a $12 \%$ SDS polyacrylamide gel and transferred onto a polyvinylidene difluoride (PVDF) membrane (Merck KGaA, Darmstadt, Germany). Membranes were probed with primary anti-PSMA (D4S1F) and anti- $\beta$-actin (13E5) monoclonal rabbit antibodies (Cell Signaling Technology Europe B.V., Frankfurt am Main, Germany), respectively. As secondary antibodies, goat anti-rabbit horseradish peroxidase (HRP) conjugates (Merck KGaA, Darmstadt, Germany) were used. For detecting HRP on immunoblots, the WesternSure PREMIUM Chemiluminescent Substrate (LI-COR Biosciences-GmbH, Bad Homburg, Germany) in combination with the C-DiGit Blot Scanner and the Image Studio software (LI-COR Biosciences-GmbH, Bad Homburg, Germany) was used.

\subsection{Saturation Binding Studies}

Saturation binding studies were performed according to a published procedure [46]. LNCaP cells were plated in 48 well culture microplates (Greiner Bio-One GmbH, Frickenhausen, Germany) at a density of $3 \times 10^{4}$ cells $/ 250 \mu \mathrm{L} /$ well and incubated for $48 \mathrm{~h}$. Before addition of [ $\left.{ }^{225} \mathrm{Ac}\right] \mathrm{Ac}-\mathrm{mcp}-\mathrm{M}-\mathrm{PSMA}$ and $\left[{ }^{225} \mathrm{Ac}\right] \mathrm{Ac}-\mathbf{m c p}$-D-PSMA, cells were preincubated for $30 \mathrm{~min}$ at $4{ }^{\circ} \mathrm{C}$. After adding a serial dilution $(15 \mathrm{pM}-500 \mathrm{nM})$ of the ${ }^{225} \mathrm{Ac}-$ labeled ligands, cells were incubated for $90 \mathrm{~min}$ at $4{ }^{\circ} \mathrm{C}$. The nonspecific binding was assessed in parallel by blocking the cells with a 1000-fold excess of unlabeled PSMA-617. 
After the incubation time, the cells were washed three times with ice-cold PBS. Finally, cells were lysed by adding 1\% SDS/0.1 M NaOH and shaking for $30 \mathrm{~min}$ at room temperature. To quantify the radioactivity in the cell extracts, an automatic gamma counter (Hidex Deutschland Vertrieb GmbH, Mainz, Germany) was used.

\subsection{Cell Viability, Apoptosis and Cell Proliferation Assays}

The treatment response on cellular proliferation was assessed using the CyQUANT direct cell proliferation assay (Thermo Fisher Scientific, Waltham, MA, USA). For this purpose, LNCaP cells were plated in black 96 well cell culture microplates (Greiner Bio-One $\mathrm{GmbH}$, Frickenhausen, Germany) at a density of $2 \times 10^{4}$ cells $/ 0.05 \mathrm{~mL} /$ well. After $24 \mathrm{~h}$, five different activity concentrations $(0.05,0.5,5,50$ and $50 \mathrm{kBq} / \mathrm{mL})$ of the ${ }^{225} \mathrm{Ac}$-labeled ligands $\left[{ }^{225} \mathrm{Ac}\right] \mathrm{Ac}-\mathbf{m c p}-\mathrm{M}$-PSMA and $\left[{ }^{225} \mathrm{Ac}\right] \mathrm{Ac}-\mathbf{m c p}-\mathrm{D}-\mathrm{PSMA}$ or the non-targeted activity control $\left[{ }^{225} \mathrm{Ac}\right] \mathrm{Ac}^{3+}$ were diluted and added in triplicate so that the final volume was $0.1 \mathrm{~mL} /$ well. After 1 or $4 \mathrm{~h}$ of incubation, the cell culture media was removed and fresh media was added to each well. Cell numbers were subsequently determined $24 \mathrm{~h}$ later as per the manufacturer's protocol. The fluorescence intensity was measured with the Varioskan Flash microplate reader (Thermo Fisher Scientific, Waltham, MA, USA).

The exposure of phosphatidylserine on the extracellular side of cell membranes during the apoptotic process was measured using the RealTime-Glo ${ }^{\mathrm{TM}}$ Annexin V Apoptosis and Necrosis assay (Promega GmbH, Walldorf, Germany). To this end, LNCaP cells were plated in white 96 well cell culture microplates (Greiner Bio-One GmbH, Frickenhausen, Germany) at a density of $2 \times 10^{4}$ cells $/ 0.05 \mathrm{~mL} /$ well. After $24 \mathrm{~h}$, five different activity concentrations $(0.05,0.5,5,50$ and $50 \mathrm{kBq} / \mathrm{mL})$ of the ${ }^{225}$ Ac-labeled ligands or the non-targeted activity control were diluted and added in triplicate so that the final volume was $0.1 \mathrm{~mL} /$ well. After 1 or $4 \mathrm{~h}$ of incubation, the cell culture media was removed and the assay reagent diluted in fresh media was added to each well. The fluorescence intensity and luminescence signals were measured for up to $24 \mathrm{~h}$ using the Varioskan Flash microplate reader (Thermo Fisher Scientific, Waltham, MA, USA).

\subsection{Colony Formation Assay}

LNCaP cells were plated in 6-well cell culture microplates (Greiner Bio-One GmbH, Frickenhausen, Germany) at a density of $6 \times 10^{3}$ cells $/ 2 \mathrm{~mL} /$ well. After $24 \mathrm{~h}$, four different activity concentrations $(0.05,0.5,5$ and $50 \mathrm{kBq} / \mathrm{mL})$ of the ${ }^{225} \mathrm{Ac}$-labeled ligands $\left[{ }^{225} \mathrm{Ac}\right] \mathrm{Ac}-$ mcp-M-PSMA and [ $\left.{ }^{225} \mathrm{Ac}\right]$ Ac-mcp-D-PSMA were added in triplicate. After 1 or $4 \mathrm{~h}$ of incubation, the cell culture media was removed and fresh media was added to each well. Plates were then incubated at $37^{\circ} \mathrm{C}$ for 8 days and re-fed every 3 to 4 days. Finally, the cell media was removed and colonies were stained with $1 \mathrm{~mL}$ of $0.5 \%$ crystal violet in $50 \%$ methanol for $30 \mathrm{~min}$, after which the plates were rinsed three times with deionized water and subsequently air-dried. The plates were scanned with an Amersham Typhoon 5 Scanner (Cytiva Europe GmbH, Freiburg, Germany) and the colonies were counted using the Image-Quant TL software (Version 8.1, Cytiva Europe GmbH, Freiburg, Germany).

\subsection{Animal Studies}

The biodistribution studies with $\left[{ }^{225} \mathrm{Ac}\right] \mathrm{Ac}-\mathbf{m c p}-\mathrm{M}-\mathrm{PSMA}$ and $\left[{ }^{225} \mathrm{Ac}\right] \mathrm{Ac}-\mathbf{m c p}-\mathrm{D}$ PSMA were performed in LNCaP tumor-bearing mice. The SCID male mice (ENVIGO, Indianapolis, IN, USA) 6-8 weeks old were subcutaneously injected into the right flank with $10 \times 10^{6}$ LNCaP cells (ATCC, Manassas, VA, USA) mixed with Matrigel Matrix (Corning, Corning, NY, USA) at a 1:1 ratio. The tumor growth was continuously monitored by caliper-based measurements. When the tumor volume reached $200-300 \mathrm{~mm}^{3}$ (i.e., 5-6 weeks after the inoculation of cells), the mice were used for biodistribution studies. The experimental animals were housed in a specific-pathogen-free animal facility. All experiments with animals were performed in accordance with appropriate legal norms (Czech Law No. 246/1992) and with the approval of the Ministry of Education, Youth and Sports (MSMT-35035/2019-3) and approval of the Ethical Committee of Faculty of Medicine and 
Dentistry, Palacky University in Olomouc. The number of animals was reduced as much as possible ( $n=4$ per group and time point) for all in vivo experiments.

For biodistribution studies, the radiotracers were diluted with saline. The prepared radiotracers were applied retro-orbitally (r.o.) to the experimental animals [47] at a dose of $50 \mathrm{kBq}$ per mouse corresponding to $10 \mathrm{pmol}$ of the peptide. The tracer injection was carried out under $2 \%$ isoflurane anesthesia (FORANE, Abbott Laboratories, Abbott Park, IL, USA) to minimize animal suffering and to prevent animal motion. The mice were sacrificed by cervical dislocation $10 \mathrm{~min}, 60 \mathrm{~min}$ and $24 \mathrm{~h}$ post-injection and organs of interest (blood, spleen, pancreas, stomach, intestine, kidneys, liver, heart, lungs, muscle, bone and tumor) were collected. The samples were weighed and the activity was measured on an automatic gamma counter. The radiotracer accumulation was expressed as a percentage of injected dose per gram $(\% \mathrm{ID} / \mathrm{g})$ of the corresponding organ.

\section{Conclusions}

Two chelators for mild condition radiolabeling with ${ }^{225}$ Ac were developed, which enable a future use not only for the application of ${ }^{225} \mathrm{Ac}$-radiolabeled peptides, but also ${ }^{225}$ Ac-radiolabeled antibodies in targeted alpha therapy. In contrast to DOTA, both chelators revealed excellent labeling yields at low chelator concentrations after short labeling times at room temperature and appropriate long-term stabilities, as well. Additionally, the therapeutic efficiency in vitro and the applicability of two PSMA-targeting model radioconjugates on LNCaP tumor-bearing mice were shown in a proof of concept study on these triazole-containing click conjugates. The presented results provide bright prospects for various future applications for ${ }^{225} \mathrm{Ac}$ in targeted alpha therapy, such as site-specific modification of bio(macro)molecules of the treatment of various types of cancer and a general improvement of DOTA-containing conjugates as well.

Supplementary Materials: The following are available online at https:/ /www.mdpi.com/article/10 $.3390 /$ cancers13081974/s1, Scheme S1: Synthesis overview for the preparation of alkyne-containing building block SI-III. Scheme S2: Synthesis of the model chelator mcp-M-COOH under click chemistry conditions. Scheme S3: Two-step synthesis approach for the click derivative PSMA-N $\mathbf{N}_{3}$. Figure S1: ${ }^{1} \mathrm{H}$ NMR and ${ }^{13} \mathrm{C}$ NMR spectra of compound SI-I. Figure S2: ${ }^{1} \mathrm{H}$ NMR and ${ }^{13} \mathrm{C}$ NMR spectra of compound SI-II. Figure S3: ${ }^{1} \mathrm{H}$ NMR and ${ }^{13} \mathrm{C}$ NMR spectra of compound SI-III. Figure S4: ${ }^{1} \mathrm{H}$ NMR spectrum of compound mcp-M-COOH. Figure S5: MS (ESI+) spectrum of compound

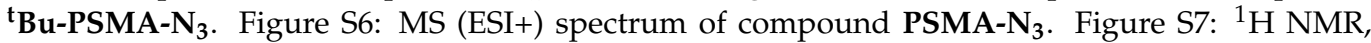
${ }^{13} \mathrm{C}$ NMR, COSY, HSQC, and MS (ESI+) spectra of compound 1. Figure S8: ${ }^{1} \mathrm{H}$ NMR, ${ }^{13} \mathrm{C}$ NMR, COSY, HSQC, and MS (ESI+) spectra of compound 2. Figure S9: ${ }^{1} \mathrm{H}$ NMR, ${ }^{13} \mathrm{C}$ NMR, COSY, HSQC, and MS (ESI+) spectra of compound 3. Figure S10. ${ }^{1} \mathrm{H}$ NMR, ${ }^{13} \mathrm{C}$ NMR, and MS (ESI+) spectra of compound mcp-M-click. Figure S11: ${ }^{1} \mathrm{H}$ NMR, ${ }^{13} \mathrm{C}$ NMR, and MS (ESI+) spectra of compound mcpD-click. Figure S12: Mass spectrum (ESI+) and expanded region of ligand mcp-M-PSMA. Figure S13: Mass spectrum (ESI+) and expanded region of ligand mcp-D-PSMA. Figure S14: Analysis of the prostate-specific membrane antigen (PSMA) expression in human prostate adenocarcinoma (LNCaP) cells. Figure S15: Analysis of the prostate-specific membrane antigen (PSMA) expression in HEK293, A431, LNCaP, PC3-PSCA, and PC3 cells. Figure S16: Biodistribution of [ ${ }^{225}$ Ac]Ac-mcp-M-PSMA (A) and $\left[{ }^{225} \mathrm{Ac}\right]$ Ac-mcp-D-PSMA (B) using healthy SCID mice $10 \mathrm{~min} .60 \mathrm{~min}$. and $24 \mathrm{~h}$ p.i. Table S1: Percentage amount of colonies referred to the non-radioactive control. Table S2: Quantitative evaluation of $\left[{ }^{225} \mathrm{Ac}\right] \mathrm{Ac}-\mathrm{mcp}-\mathrm{M}-\mathrm{PSMA}$ in LNCaP tumor-bearing SCID mice. The values are given as the mean of the percentage of injected dose per gram of organ \pm standard deviation $(n=4)$. Table S3: Quantitative evaluation of [ $\left.{ }^{225} \mathrm{Ac}\right]$ Ac-mcp-D-PSMA in LNCaP tumor-bearing SCID mice. The values are given as the mean of the percentage of injected dose per gram of organ \pm standard deviation $(n=4)$. Table S4: Quantitative evaluation of $\left[{ }^{225} \mathrm{Ac}\right] \mathrm{Ac}-\mathbf{m c p}-\mathbf{M}-\mathbf{P S M A}$ in healthy mice. Table S5: Quantitative evaluation of $\left[{ }^{225} \mathrm{Ac}\right] \mathrm{Ac}-\mathrm{mcp}$-D-PSMA in healthy mice.

Author Contributions: Conceptualization, F.R., K.Z. and C.M.; methodology, F.R., K.Z., M.-C.L., Z.N., M.P. and K.B.; validation, F.R., D.B., K.Z., M.-C.L., Z.N. and K.B.; formal analysis, F.R., D.B., K.Z., M.-C.L., Z.N. and K.B.; investigation, F.R., K.Z., Z.N. and C.M.; resources, K.K. and M.P.; data curation, F.R., D.B., K.Z., M.-C.L., Z.N., K.B. and M.P.; writing-original draft preparation, F.R., 
K.Z. and C.M.; writing-review and editing, all authors; visualization, F.R., K.Z., Z.N. and C.M.; supervision, K.K. and M.P.; project administration, K.K., H.-J.P. and C.M.; funding acquisition, Z.N. and M.P. All authors have read and agreed to the published version of the manuscript.

Funding: This research was funded by the Czech Ministry of Education, Youth and Sports, project No. LM2018133 and by the European Regional Development Fund-Project ENOCH (No. CZ.02.1.01/0.0/0.0/16_019/0000868).

Institutional Review Board Statement: All experiments with animals were performed in accordance with appropriate legal norms (Czech Law No. 246/1992) and with the approval of the Ministry of Education, Youth and Sports (MSMT-35035/2019-3) and approval of the Ethical committee of Faculty of Medicine and Dentistry, Palacky University in Olomouc.

Data Availability Statement: The data presented in this study are available in the Supplementary Materials.

Acknowledgments: The authors thank Utta Herzog and Linda Belke for excellent technical assistance.

Conflicts of Interest: PSMA-617 is the subject of a patent where K.K. is involved as co-inventor. No other conflicts of interest relevant to this article were reported. The other authors declare no conflicts of interest.

\section{References}

1. Nayak, T.; Norenberg, J.; Anderson, T.; Atcher, R. A comparison of high- versus low-linear energy transfer somatostatin receptor targeted radionuclide therapy in vitro. Cancer Biother. Radiopharm. 2005, 20, 52-57. [CrossRef] [PubMed]

2. Zalutsky, M.R.; Reardon, D.A.; Pozzi, O.R.; Vaidyanathan, G.; Bigner, D.D. Targeted alpha-particle radiotherapy with ${ }^{211}$ At-labeled monoclonal antibodies. Nucl. Med. Biol. 2007, 34, 779-785. [CrossRef]

3. Zalutsky, M.R.; Pruszynski, M. Astatine-211: Production and availability. Curr. Radiopharm. 2011, 4, 177-185. [CrossRef] [PubMed]

4. Vaidyanathan, G.; Zalutsky, M.R. Applications of ${ }^{211}$ At and ${ }^{223}$ Ra in targeted alpha-particle radiotherapy. Curr. Radiopharm. 2011, 4, 283-294. [CrossRef]

5. Choi, J.; Vaidyanathan, G.; Koumarianou, E.; Kang, C.M.; Zalutsky, M.R. Astatine-211 labeled anti-HER2 5F7 single domain antibody fragment conjugates: Radiolabeling and preliminary evaluation. Nucl. Med. Biol. 2018, 56, 10-20. [CrossRef]

6. Thiele, N.A.; Wilson, J.J. Actinium-225 for Targeted $\alpha$ Therapy: Coordination Chemistry and Current Chelation Approaches. Cancer Biother. Radiopharm. 2018, 33, 336-348. [CrossRef]

7. Roscher, M.; Bakos, G.; Benešová, M. Atomic Nanogenerators in Targeted Alpha Therapies: Curie's Legacy in Modern Cancer Management. Pharmaceuticals 2020, 13, 76. [CrossRef]

8. Kratochwil, C.; Giesel, F.L.; Bruchertseifer, F.; Mier, W.; Apostolidis, C.; Boll, R.; Murphy, K.; Haberkorn, U.; Morgenstern, A. ${ }^{213} \mathrm{Bi}$-DOTATOC receptor-targeted alpha-radionuclide therapy induces remission in neuroendocrine tumours refractory to beta radiation: A first-in-human experience. Eur. J. Nucl. Med. Mol. Imaging 2014, 41, 2106-2119. [CrossRef]

9. Kratochwil, C.; Schmidt, K.; Afshar-Oromieh, A.; Bruchertseifer, F.; Rathke, H.; Morgenstern, A.; Haberkorn, U.; Giesel, F.L. Targeted alpha therapy of mCRPC: Dosimetry estimate of ${ }^{213}$ Bismuth-PSMA-617. Eur. J. Nucl. Med. Mol. Imaging 2018, $45,31-37$. [CrossRef] [PubMed]

10. Poeppel, T.D.; Handkiewicz-Junak, D.; Andreeff, M.; Becherer, A.; Bockisch, A.; Fricke, E.; Geworski, L.; Heinzel, A.; Krause, B.J.; Krause, T.; et al. EANM guideline for radionuclide therapy with radium-223 of metastatic castration-resistant prostate cancer. Eur. J. Nucl. Med. Mol. Imaging 2018, 45, 824-845. [CrossRef]

11. Gott, M.; Steinbach, J.; Mamat, C. The radiochemical and radiopharmaceutical applications of radium. Open Chem. 2016, 14, 118-129. [CrossRef]

12. Steinberg, J.; Bauer, D.; Reissig, F.; Köckerling, M.; Pietzsch, H.-J.; Mamat, C. Modified Calix[4]crowns as Molecular Receptors for Barium. ChemistryOpen 2018, 7, 432-438. [CrossRef]

13. Bauer, D.; Gott, M.; Steinbach, J.; Mamat, C. Chelation of heavy group 2 (radio)metals by p-tert-butylcalix[4]arene-1,3-crown-6 and $\log$ K determination via NMR. Spectrochim. Acta A 2018, 199, 50-56. [CrossRef] [PubMed]

14. Bauer, D.; Blumberg, M.; Köckerling, M.; Mamat, C. A Comparative Evaluation of Calix[4]arene-1,3-crown-6 as a Ligand for Selected Divalent Cations of Radiopharmaceutical Interest. RSC Adv. 2019, 9, 32357-32366. [CrossRef]

15. Abou, D.S.; Thiele, N.A.; Gutsche, N.T.; Villmer, A.; Zhang, H.; Woods, J.J.; Baidoo, K.E.; Escorcia, F.E.; Wilson, J.J.; Thorek, D.L.J. Towards the stable chelation of radium for biomedical applications with an 18-membered macrocyclic ligand. Chem. Sci. 2021, 12, 3733-3742. [CrossRef]

16. Reissig, F.; Bauer, D.; Pietzsch, H.-J.; Steinbach, J.; Mamat, C. Synthesis and functionalization of radium-doped barium sulfate nanoparticles. J. Med. Imag. Radiat. Sci. 2019, 50, S38. [CrossRef]

17. Reissig, F.; Zarschler, K.; Hübner, R.; Pietzsch, H.-J.; Kopka, K.; Mamat, C. Sub-10 nm barium sulfate nanoparticles as universal radionuclide carriers for theranostic applications and targeted alpha therapy. ChemistryOpen 2020, 9, 797-805. [CrossRef] 
18. Bilewicz, A.; Cedrowska, E.; Gaweda, W.; Bruchertseifer, F.; Morgenstern, A. Barium ferrite magnetic nanoparticles labeled with ${ }^{223} \mathrm{Ra}$ : A new potential magnetic radiobioconjugate for targeted alpha therapy. J. Label. Compds. Radiopharm. 2019, 62, 103. [CrossRef]

19. Vasiliev, A.N.; Severin, A.; Lapshina, E.; Chernykh, E.; Ermolaev, S.; Kalmykov, S. Hydroxyapatite particles as carriers for ${ }^{223}$ Ra. J. Radioanal. Nucl. Chem. 2017, 311, 1503-1509. [CrossRef]

20. Suchánková, P.; Kukleva, E.; Štamberg, K.; Nykl, P.; Vlk, M.; Kozempel, J. Study of ${ }^{223}$ Ra uptake mechanism on hydroxyapatite and titanium dioxide nanoparticles as a function of pH. RSC Adv. 2020, 10, 3659-3666. [CrossRef]

21. Gott, M.; Yang, P.; Kortz, U.; Stephan, H.; Pietzsch, H.-J.; Mamat, C. Evaluation of Barium and Radium Polyoxopalladates for Radiopharmaceutical Applications. Chem. Commun. 2019, 55, 7631-7634. [CrossRef]

22. Hagemann, U.B.; Ellingsen, C.; Schuhmacher, J.; Kristian, A.; Mobergslien, A.; Cruciani, V.; Wickstroem, K.; Schatz, C.A.; Kneip, C.; Golfier, S.; et al. Mesothelin-Targeted Thorium-227 Conjugate (MSLN-TTC): Preclinical Evaluation of a New Targeted Alpha Therapy for Mesothelin-Positive Cancers. Clin. Cancer Res. 2019, 25, 4723-4734. [CrossRef]

23. Levy, M.Y.; Cicic, D.; Bergonio, G.; Berger, M. Trial in Progress: Phase I Study of Actinium-225 ( ${ }^{225}$ Ac)-Lintuzumab in Patients with Refractory Multiple Myeloma. Clin. Lymphoma Myeloma Leuk. 2017, 17, S329-S330. [CrossRef]

24. Kratochwil, C.; Bruchertseifer, F.; Giesel, F.L.; Weis, M.; Verburg, F.A.; Mottaghy, F.; Kopka, K.; Apostolidis, C.; Haberkorn, U.; Morgenstern, A. ${ }^{225}$ Ac-PSMA-617 for PSMA-Targeted $\alpha$-Radiation Therapy of Metastatic Castration-Resistant Prostate Cancer. J. Nucl. Med. 2016, 57, 1941-1944. [CrossRef] [PubMed]

25. Thiele, N.A.; Brown, V.; Kelly, J.M.; Amor-Coarasa, A.; Jermilova, U.; MacMillan, S.N.; Nikolopoulou, A.; Ponnala, S.; Ramogida, C.F.; Robertson, A.K.H.; et al. An Eighteen-Membered Macrocyclic Ligand for Actinium-225 Targeted Alpha Therapy. Angew. Chem. Int. Ed. Engl. 2017, 56, 14712-14717. [CrossRef] [PubMed]

26. Roca-Sabio, A.; Mato-Iglesias, M.; Esteban-Gómez, D.; de Blas, A.; Rodríguez-Blas, T.; Platas-Iglesias, C. The effect of ring size variation on the structure and stability of lanthanide(III) complexes with crown ethers containing picolinate pendants. Dalton Trans. 2011, 40, 384-392. [CrossRef] [PubMed]

27. Kelly, J.M.; Amor-Coarasa, A.; Ponnala, S.; Nikolopoulou, A.; Williams, C., Jr.; Thiele, N.A.; Schlyer, D.; Wilson, J.J.; DiMagno, S.G.; Babich, J.W. A Single Dose of ${ }^{225}$ Ac-RPS-074 Induces a Complete Tumor Response in an LNCaP Xenograft Model. J. Nucl. Med. 2019, 60, 649-655. [CrossRef]

28. Thirumurugan, P.; Dariusz Matosiuk, D.; Jozwiak, K. Click Chemistry for Drug Development and Diverse Chemical-Biology Applications. Chem. Rev. 2013, 113, 4905-4979. [CrossRef]

29. Roca-Sabio, A.; Mato-Iglesias, M.; Esteban-Gómez, D.; Tóth, E.; de Blas, A.; Platas-Iglesias, C.; Rodríguez-Blas, T. Macrocyclic receptor exhibiting unprecedented selectivity for light lanthanides. J. Am. Chem. Soc. 2009, 131, 3331-3341. [CrossRef]

30. Kozempel, J.; Mokhodoeva, O.; Vlk, M. Progress in Targeted Alpha-Particle Therapy. What We Learned about Recoils Release from In Vivo Generators. Molecules 2018, 23, 581. [CrossRef]

31. de Kruijff, R.M.; Wolterbeek, H.T.; Denkova, A.G. A Critical Review of Alpha Radionuclide Therapy-How to Deal with Recoiling Daughters? Pharmaceuticals 2015, 8, 321-336. [CrossRef] [PubMed]

32. Yang, H.; Zhang, C.; Yuan, Z.; Rodriguez-Rodriguez, C.; Robertson, A.; Radchenko, V.; Perron, R.; Gendron, D.; Causey, P.; Gao, F.; et al. Synthesis and Evaluation of a Macrocyclic Actinium-225 Chelator, Quality Control and In Vivo Evaluation of 225 Ac-crown- $\alpha$ MSH Peptide. Chem. Eur. J. 2020, 26, 11435-11440. [CrossRef]

33. Schäfer, M.; Bauder-Wüst, U.; Leotta, K.; Zoller, F.; Mier, W.; Haberkorn, U.; Eisenhut, M.; Eder, M. A dimerized urea-based inhibitor of the prostate-specific membrane antigen for ${ }^{68} \mathrm{Ga}$-PET imaging of prostate cancer. EJNMMI Res. 2012, 2, 23. [CrossRef] [PubMed]

34. Frei, A.; Fischer, E.; Childs, B.C.; Holland, J.P.; Alberto, R. Two is better than one: Difunctional high-affinity PSMA probes based on a $\left[\mathrm{CpM}(\mathrm{CO})_{3}\right]\left(\mathrm{M}=\mathrm{Re} /{ }^{99 \mathrm{~m}} \mathrm{Tc}\right)$ scaffold. Dalton Trans. 2019, 48, 14600-14605. [CrossRef] [PubMed]

35. Mammen, M.; Choi, S.K.; Whitesides, G.M. Polyvalent Interactions in Biological Systems: Implications for Design and Use of Multivalent Ligands and Inhibitors. Angew. Chem. Int. Ed. Engl. 1998, 37, 2754-2794. [CrossRef]

36. Silver, D.A.; Pellicer, I.; Fair, W.R.; Heston, W.D.; Cordon-Cardo, C. Prostate-specific membrane antigen expression in normal and malignant human tissues. Clin. Cancer Res. 1997, 3, 81-85.

37. O'Keefe, D.S.; Bacich, D.J.; Heston, W.D. Comparative analysis of prostate-specific membrane antigen (PSMA) versus a prostatespecific membrane antigen-like gene. Prostate 2004, 58, 200-210. [CrossRef]

38. Kinoshita, Y.; Kuratsukuri, K.; Landas, S.; Imaida, K.; Rovito, P.M., Jr.; Wang, C.Y.; Haas, G.P. Expression of prostate-specific membrane antigen in normal and malignant human tissues. World J. Surg. 2006, 30, 628-636. [CrossRef]

39. Eder, M.; Schäfer, M.; Bauder-Wüst, U.; Haberkorn, U.; Eisenhut, M.; Kopka, K. Preclinical evaluation of a bispecific low-molecular heterodimer targeting both PSMA and GRPR for improved PET imaging and therapy of prostate cancer. Prostate 2014, 74, 659-668. [CrossRef]

40. Dam, J.H.; Olsen, B.B.; Baun, C.; Høilund-Carlsen, P.F.; Thisgaard, H. A PSMA Ligand Labeled with Cobalt-55 for PET Imaging of Prostate Cancer. Mol. Imaging Biol. 2017, 19, 915-922. [CrossRef]

41. Benešová, M.; Schäfer, M.; Bauder-Wüst, U.; Afshar-Oromieh, A.; Kratochwil, C.; Mier, W.; Haberkorn, U.; Kopka, K.; Eder, M. Preclinical Evaluation of a Tailor-Made DOTA-Conjugated PSMA Inhibitor with Optimized Linker Moiety for Imaging and Endoradiotherapy of Prostate Cancer. J. Nucl. Med. 2015, 56, 914-920. [CrossRef] 
42. Weineisen, M.; Schottelius, M.; Simecek, J.; Baum, R.P.; Yildiz, A.; Beykan, S.; Kulkarni, H.R.; Lassmann, M.; Klette, I.; Eiber, M.; et al. ${ }^{68} \mathrm{Ga}$ - and ${ }^{177} \mathrm{Lu}$-Labeled PSMA I\&T: Optimization of a PSMA-Targeted Theranostic Concept and First Proof-ofConcept Human Studies. J. Nucl. Med. 2015, 56, 1169-1176. [CrossRef] [PubMed]

43. Wurzer, A.; Parzinger, M.; Konrad, M.; Beck, R.; Günther, T.; Felber, V.; Färber, S.; Di Carlo, D.; Wester, H.J. Preclinical comparison of four $\left[{ }^{18} \mathrm{~F}\right.$, nat $\left.\mathrm{Ga}\right] \mathrm{rhPSMA}-7$ isomers: Influence of the stereoconfiguration on pharmacokinetics. EJNMMI Res. 2020, 10, 149. [CrossRef]

44. Hanna, J.R.; Allan, C.; Lawrence, C.; Meyer, O.; Wilson, N.D.; Hulme, A.N. Optimizing the Readout of Lanthanide-DOTA Complexes for the Detection of Ligand-Bound Copper(I). Molecules 2017, 22, 802. [CrossRef] [PubMed]

45. Laemmli, U.K. Cleavage of structural proteins during the assembly of the head of bacteriophage T4. Nature 1970, 227, 680-685. [CrossRef] [PubMed]

46. Taylor, R.M.; Severns, V.; Brown, D.C.; Bisoffi, M.; Sillerud, L.O. Prostate cancer targeting motifs: Expression of $\alpha_{v} \beta_{3}$, neurotensin receptor 1, prostate specific membrane antigen, and prostate stem cell antigen in human prostate cancer cell lines and xenografts. Prostate 2012, 72, 523-532. [CrossRef] [PubMed]

47. Kirchhoff, F.; Debarbieux, F.; Kronland-Martinet, C.; Cojocaru, G.R.; Popa-Wagner, A. Combined two-photon laser-scanning microscopy and spectral microCT X-ray imaging to characterize the cellular signature and evolution of microstroke foci. Rom. J. Morphol. Embryol. 2012, 53, 671-675. 